\title{
Simulation of Ground-Water Flow and Solute Transport in the Glen Canyon Aquifer, East-Central Utah
}

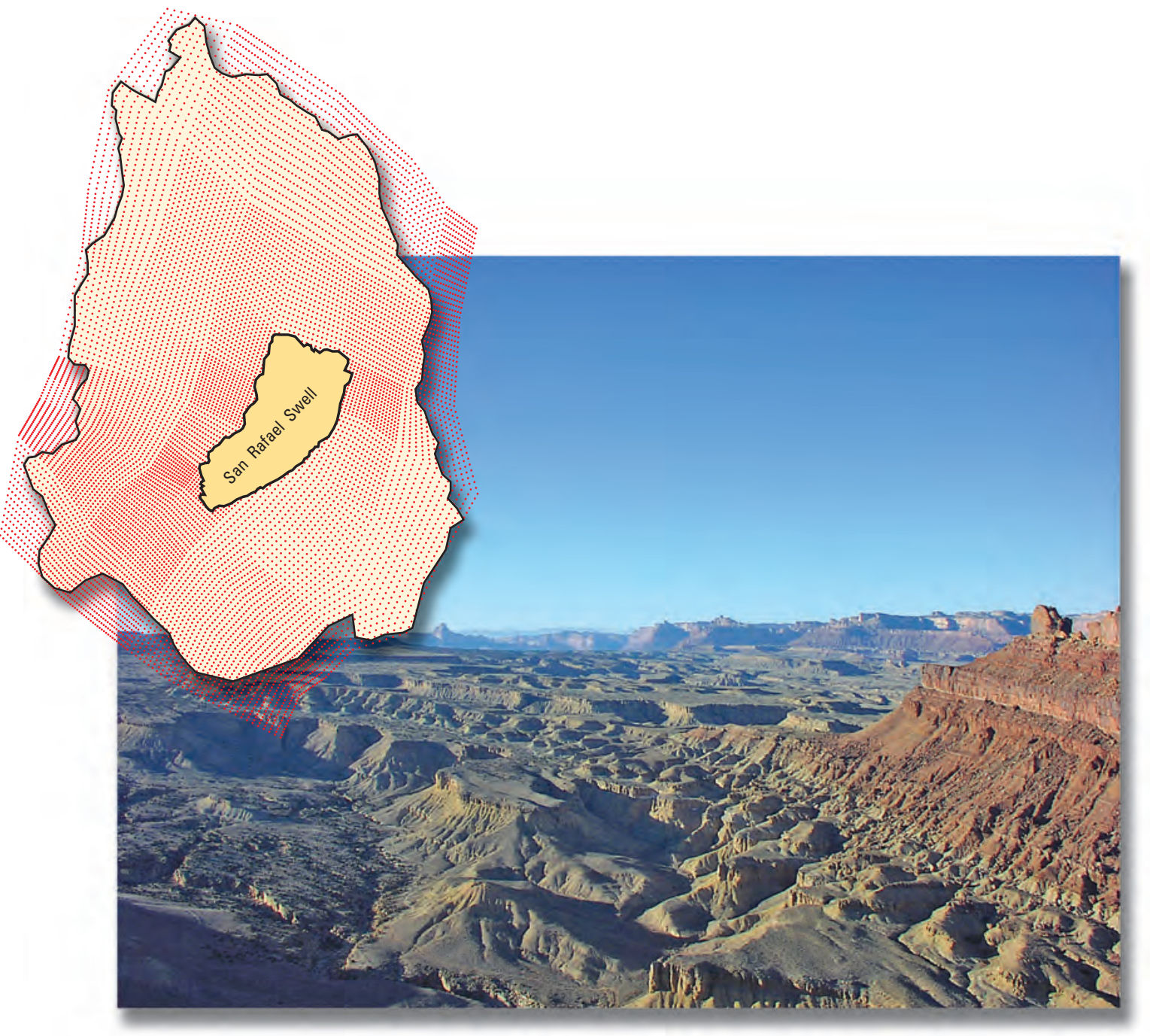

Prepared in cooperation with the Utah Department of Natural Resources, Division of Oil, Gas, and Mining

Scientific Investigations Report 2009-5037

U.S. Department of the Interior

U.S. Geological Survey 
Cover photograph: View looking west across the San Rafael Swell, Utah, from the reef above Black Dragon Canyon, January 19, 2003. 


\section{Simulation of Ground-Water Flow and Solute Transport in the Glen Canyon Aquifer, East-Central Utah}

By Geoffrey W. Freethey and Bernard J. Stolp

Prepared in cooperation with the Utah Department of Natural Resources, Division of Oil, Gas, and Mining

Scientific Investigations Report 2009-5037 


\title{
U.S. Department of the Interior \\ KEN SALAZAR, Secretary
}

\author{
U.S. Geological Survey \\ Suzette M. Kimball, Acting Director
}

U.S. Geological Survey, Reston, Virginia: 2010

For product and ordering information:

World Wide Web: http://www.usgs.gov/pubprod

Telephone: 1-888-ASK-USGS

For more information on the USGS--the Federal source for science about the Earth, its natural and living resources, natural hazards, and the environment:

World Wide Web: http://www.usgs.gov

Telephone: 1-888-ASK-USGS

Any use of trade, product, or firm names is for descriptive purposes only and does not imply endorsement by the U.S. Government.

Although this report is in the public domain, permission must be secured from the individual copyright owners to reproduce any copyrighted materials contained within this report.

Suggested citation:

Freethey, G.W. and Stolp, B.J., 2010, Simulation of ground-water flow and solute transport in the Glen Canyon aquifer, East-Central Utah: U.S. Geological Survey Scientific Investigations Report 2009-5037, 28 p.

Available at http://pubs.usgs.gov/sir/2009/5037. 


\section{Contents}

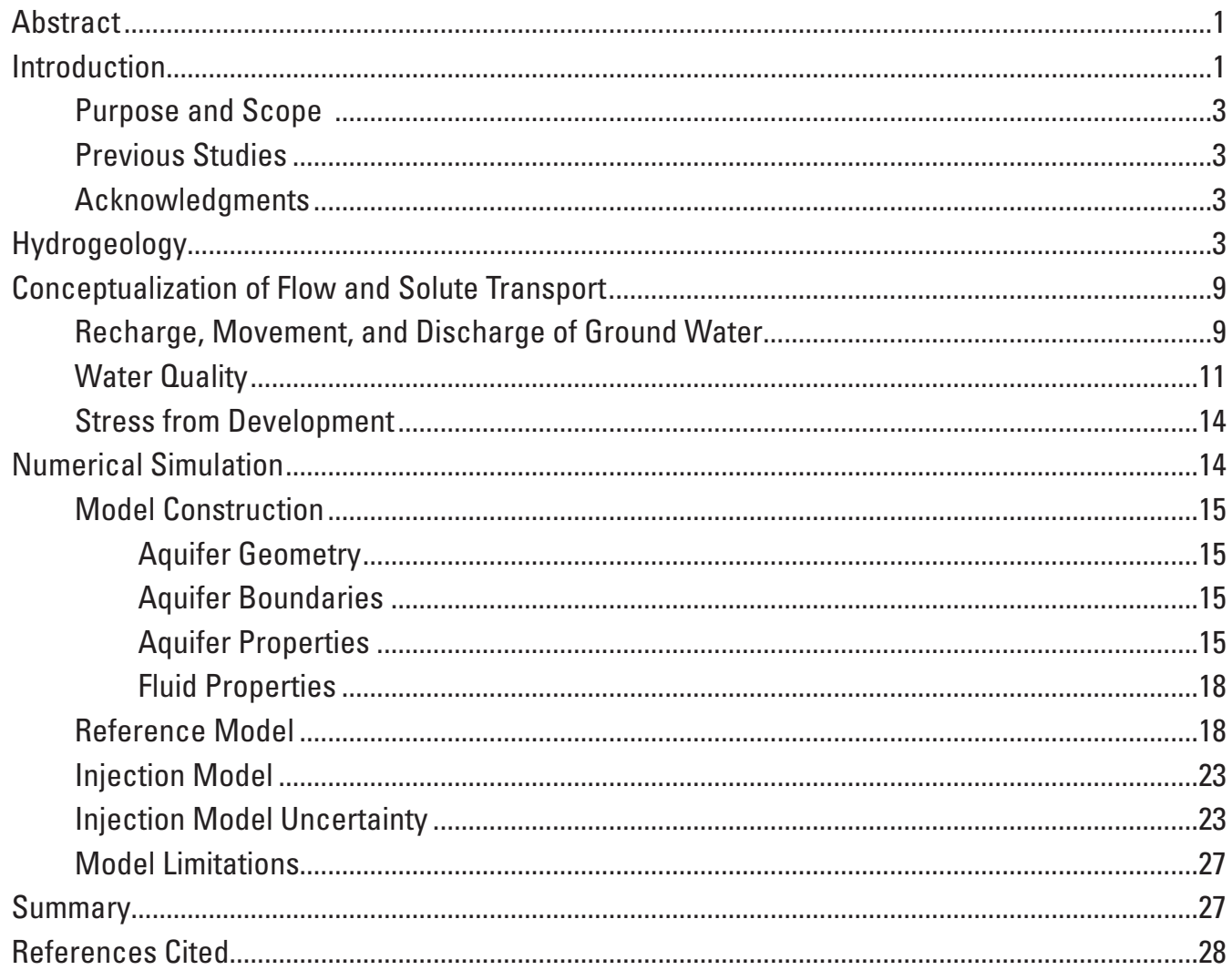

\section{Figures}

1. Map showing location of geographic features and active gas fields in the Glen Canyon aquifer study area, Utah

2. Map showing approximate pre-erosion altitude of the top of the Navajo Sandstone in the Glen Canyon aquifer study area, Utah .................................................... 4

3. Map showing approximate pre-erosion thickness of the Navajo Sandstone in the Glen Canyon aquifer study area, Utah ...................................................... 5

4. Map showing approximate pre-erosion thickness of the Kayenta Formation in the Glen Canyon aquifer study area, Utah ....................................................... 6

5. Map showing approximate pre-erosion thickness of the Wingate Sandstone in the

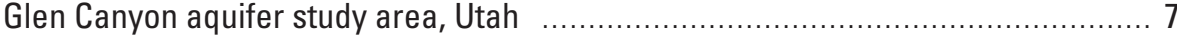

6. Map showing outcrop areas for the Navajo Sandstone, Kayenta Formation, and Wingate Sandstone, and structural features in and around the Glen Canyon aquifer study area, Utah

7. Map showing estimated distribution of $A$, porosity and $B$, hydraulic conductivity in the Glen Canyon aquifer study area, Utah

8. Map showing estimated distribution of water levels and assumed direction of ground-water movement in the Glen Canyon aquifer study area, Utah 
9. Map showing $A$, estimated dissolved-solids concentration contours and $B$, a generalized dissolved-solids concentration distribution for ground water in the Glen Canyon aquifer study area, Utah

10. Map showing model $A$, nodes and $B$, elements used to simulate ground-water flow and solute transport in the Glen Canyon aquifer study area, Utah

11. Map showing elements where sources of fluid and solute are specified to simulate recharge, and nodes where water pressures are specified to simulate discharge at rivers and springs in the Glen Canyon aquifer study area, Utah

12. Map showing observation points used to adjust permeability and to estimate projected changes in fresh-water equivalent water levels and dissolved-solids concentrations in the model of the Glen Canyon aquifer study area, Utah

13. Map showing the final distribution of horizontal permeability values for the Navajo Sandstone (model layer 1) as simulated in the reference model of the Glen Canyon aquifer study area, Utah

14. Map showing final distribution of porosity values for the Navajo Sandstone (model layer 1) as simulated in the reference model of the Glen Canyon aquifer study area, Utah

15. Map showing direction of ground-water flow in the Navajo Sandstone (model layer 1) and areas where fresh-water equivalent water levels are below the top of the Navajo Sandstone as simulated in the reference model of the Glen Canyon aquifer study area, Utah

16. Map showing areas where $A$, fresh-water equivalent water levels changed by more than 50 feet and $B$, where dissolved-solids concentrations changed by more than 100 milligrams per liter, overlain on the dissolved-solids concentration distribution simulated for the Navajo Sandstone (model Layer 1) at the end of stress period 7 in the injection model of the Glen Canyon aquifer study area, Utah

17. Graphs showing $A$, changes in fresh-water equivalent water levels and concentrations of dissolved solids, and $B$, amounts of discharge and solute load to rivers, simulated for the Glen Canyon aquifer study area, Utah

18. Graphs showing amounts of discharge and solute load to rivers simulated at the end of stress period 7 in the injection model of the Glen Canyon aquifer study area, Utah

\section{Tables}

1. Conceptual ground-water budget for the active flow areas in the Glen Canyon aquifer study area, Utah.

2. Amount and quality of water injected into the Glen Canyon aquifer study area, Utah.

3. Simulated ground-water and solute budgets for the reference model, the 36-year reference model, the injection model at the end of stress period 7 , and the conceptual ground-water budget for the Glen Canyon aquifer study area, Utah.

4. Stress periods and amounts of injected coal-bed methane production water that is simulated in the injection model of the Glen Canyon aquifer study area, Utah. 


\section{Conversion Factors, Datums, and Abbreviated Water-Quality Units}

\begin{tabular}{|c|c|c|}
\hline Multiply & By & To obtain \\
\hline \multicolumn{3}{|c|}{ Length } \\
\hline foot $(\mathrm{ft})$ & 0.3048 & meter $(\mathrm{m})$ \\
\hline mile (mi) & 1.609 & kilometer (km) \\
\hline \multicolumn{3}{|c|}{ Area } \\
\hline square mile $\left(\mathrm{mi}^{2}\right)$ & 2.590 & square kilometer $\left(\mathrm{km}^{2}\right)$ \\
\hline \multicolumn{3}{|c|}{ Volume } \\
\hline acre-foot (acre-ft) & 1,233 & cubic meter $\left(\mathrm{m}^{3}\right)$ \\
\hline acre-foot (acre-ft) & 0.001233 & cubic hectometer $\left(\mathrm{hm}^{3}\right)$ \\
\hline \multicolumn{3}{|c|}{ Flow rate, hydraulic conductivity, and transmissivity ${ }^{1}$} \\
\hline acre-foot per year (acre-ft/yr) & 1,233 & cubic meter per year $\left(\mathrm{m}^{3} / \mathrm{yr}\right)$ \\
\hline acre-foot per year (acre-ft/yr) & 0.001233 & cubic hectometer per year $\left(\mathrm{hm}^{3} / \mathrm{yr}\right)$ \\
\hline foot per day (ft/d) & $3.528 \times 10^{-6}$ & meter per second $(\mathrm{m} / \mathrm{s})$ \\
\hline foot squared per day $\left(\mathrm{ft}^{2} / \mathrm{d}\right)$ & $1.075 \times 10^{-6}$ & meter squared per second $\left(\mathrm{m}^{2} / \mathrm{s}\right)$ \\
\hline \multicolumn{3}{|c|}{ Mass } \\
\hline ton, short $(2,000 \mathrm{lb})$ & 0.9072 & megagram $(\mathrm{Mg})$ \\
\hline ton per year (ton/yr) & 0.9072 & metric ton per year (ton/yr) \\
\hline ton per year (ton/yr) & 3.8351 & kilogram per second $(\mathrm{kg} / \mathrm{s})$ \\
\hline \multicolumn{3}{|c|}{ Fluid density } \\
\hline pound per cubic foot $\left(\mathrm{lb} / \mathrm{ft}^{3}\right)$ & 16.0185 & kilogram per cubic meter $\left(\mathrm{kg} / \mathrm{m}^{3}\right)$ \\
\hline
\end{tabular}

${ }^{1}$ Transmissivity: The standard unit for transmissivity is cubic foot per day per square foot times foot of aquifer thickness $\left[\left(\mathrm{ft}^{3} / \mathrm{d}\right) / \mathrm{ft}^{2}\right] \mathrm{ft}$. In this report, the mathematically reduced form, foot squared per day $\left(\mathrm{ft}^{2} / \mathrm{d}\right)$, is used for convenience.

Vertical coordinate information is referenced to the National Geodetic Vertical Datum of 1929 (NGVD 29); horizontal coordinate information is referenced to the North American Datum of 1983 (NAD 83). Altitude, as used in this report, refers to distance above the vertical datum.

In this report, fluid viscosity, the coefficient of fluid-density-change as a function of chemical concentration, solid-matrix compressibility, the acceleration of gravity, the compressibility of water, chemical concentration, longitudinal and transverse dispersivity, permeability, and fluid pressure are reported in International System (SI) units. Fluid viscosity is set at 0.001 kilograms per metersecond $(\mathrm{kg} / \mathrm{ms})$. The coefficient of fluid-density-change as a function of chemical concentration is set at 700 kilograms per meter cubed $\left(\mathrm{kg} / \mathrm{m}^{3}\right)$. Solid-matrix compressibility is set at $1 \times 10^{-10}$ metersecond squared per kilogram $\left(\mathrm{ms}^{2} / \mathrm{kg}\right)$. The acceleration of gravity is set at 9.81 meters per second squared $\left(\mathrm{m} / \mathrm{s}^{2}\right)$. Compressibility of water is set at $4.4 \times 10^{-10}$ meter-second squared per kilogram $\left(\mathrm{ms}^{2} / \mathrm{kg}\right)$. Chemical concentration in water is reported in milligrams per liter $(\mathrm{mg} / \mathrm{L})$. Longitudinal and transverse dispersivity are reported in meters $(\mathrm{m})$. Permeability is reported in meters squared $\left(\mathrm{m}^{2}\right)$. Fluid pressure is reported in kilograms per meter-second squared $\left(\mathrm{kg} / \mathrm{ms}^{2}\right)$. 
Permeability and fluid pressure are used in the variable density model. Permeability $(k)$ is an intrinsic property of material and independent of the fluid flowing through it. Fluid pressure (p) incorporates the effects of density on the hydraulic head (h) of the fluid in the aquifer. Permeability can be converted to hydraulic conductivity $(K)$ in units of meters per second $(\mathrm{m} / \mathrm{s})$ and hydraulic conductivity can be converted to permeability using fluid viscosity $(\mu)$, fluid density $(\rho)$, and the acceleration of gravity ( $g$ ) as follows:

$\mathrm{K}=(\mathrm{k} \times \rho \times \mathrm{g}) / \mu$

$k=(K \times \mu) /(\rho \times g)$

Fluid pressure (p) can be converted to water-level altitude (or hydraulic head [h]) in units of meters $(\mathrm{m})$ and water-level altitude can be converted to fluid pressure using the altitude of the point of measurement [or elevation head ( $\mathrm{z})$ ] in meters, the acceleration of gravity $(\mathrm{g})$, and fluid density $(\rho)$ as follows:

$h=p /(\rho \times g)+z$

$p=(h-z) \times g \times \rho$

In this report, the fluid density used to convert between fluid pressure and water-level altitude is 998.2 kilograms per meter cubed $\left(\mathrm{kg} / \mathrm{m}^{3}\right)$. 


\title{
Simulation of Ground-Water Flow and Solute Transport in the Glen Canyon Aquifer, East-Central Utah
}

\author{
By Geoffrey W. Freethey and Bernard J. Stolp
}

\section{Abstract}

The extraction of methane from coal beds in the Ferron coal trend in central Utah started in the mid-1980s. Beginning in 1994, water from the extraction process was pressureinjected into the Glen Canyon aquifer. The lateral extent of the aquifer that could be affected by injection is about 7,600 square miles. To address regional-scale effects of injection over a decadal time frame, a conceptual model of ground-water movement and transport of dissolved solids was formulated. A numerical model that incorporates aquifer concepts was then constructed and used to simulate injection.

The Glen Canyon aquifer within the study area is conceptualized in two parts - an active area of ground-water flow and solute transport that exists between recharge areas in the San Rafael Swell and Desert, Waterpocket Fold, and Henry Mountains and discharge locations along the Muddy, Dirty Devil, San Rafael, and Green Rivers. An area of little or negligible ground-water flow exists north of Price, Utah, and beneath the Wasatch Plateau. Pressurized injection of coal-bed methane production water occurs in this area where dissolvedsolids concentrations can be more than 100,000 milligrams per liter. Injection has the potential to increase hydrologic interaction with the active flow area, where dissolved-solids concentrations are generally less than 3,000 milligrams per liter.

Pressurized injection of coal-bed methane production water in 1994 initiated a net addition of flow and mass of solutes into the Glen Canyon aquifer. To better understand the regional scale hydrologic interaction between the two areas of the Glen Canyon aquifer, pressurized injection was numerically simulated. Data constraints precluded development of a fully calibrated simulation; instead, an uncalibrated model was constructed that is a plausible representation of the conceptual flow and solute-transport processes. The amount of injected water over the 36-year simulation period is about 25,000 acre-feet. As a result, simulated water levels in the injection areas increased by 50 feet and dissolved-solids concentrations increased by 100 milligrams per liter or more. These increases are accrued into aquifer storage and do not extend to the rivers during the 36-year simulation period. The amount of change in simulated discharge and solute load to the rivers is less than the resolution accuracy of the numerical simulation and is interpreted as no significant change over the considered time period.

\section{Introduction}

The extraction of methane from coal beds in the Ferron coal trend in central Utah began in the mid-1980s. Coal typically stores six to seven times more methane than equivalent rock volumes of a conventional gas reservoir (Nuccio, 1997). In order for methane to be released from coal beds, water is pumped from the surrounding sandstone. This decreases the hydrostatic pressure and allows the coal to degas methane. Water produced from the sandstone is slightly to moderately saline and needs to be disposed of in an efficient and cost-effective way. Pond evaporation was attempted but was infeasible for the volume of water being produced. Pressurized injection of coal-bed methane production water into the Glen Canyon aquifer, which is hundreds of feet below the Ferron coal beds, was determined to be the most efficient method of disposal.

The Glen Canyon aquifer is composed of the Navajo Sandstone, the Kayenta Formation, and the Wingate Sandstone where they are saturated. The aquifer is contiguous throughout the study area except in the San Rafael Swell where the geologic units have been removed by erosion or are unsaturated. The lateral extent of the aquifer that potentially could be affected by pressurized injection is bounded on the west by the Wasatch Plateau, on the north by the Book Cliffs, on the east by the Green River, and on the south by the Henry Mountains (fig. 1). The study area encompasses about $7,600 \mathrm{mi}^{2}$. The Glen Canyon aquifer within the study area is conceptualized in two parts - an active area of ground-water flow and solute transport that exists between recharge areas in the San Rafael Swell and Desert, Waterpocket Fold, and Henry Mountains, and discharge locations along the Muddy, Dirty Devil, San Rafael, and Green Rivers. An area of little or negligible ground-water flow exists north of Price and beneath the Wasatch Plateau. Pressurized injection of coal-bed methane production water occurs in this area where dissolvedsolids concentrations can be more than 100,000 milligrams per liter. Injection has the potential to increase hydrologic interaction with the active flow area, where dissolved-solids concentrations are generally less than 3,000 milligrams per liter.

Local effects of injection, such as water-quality changes and hydrofracturing, are monitored by injection-well operators where possible. Interaction between active and negligible 


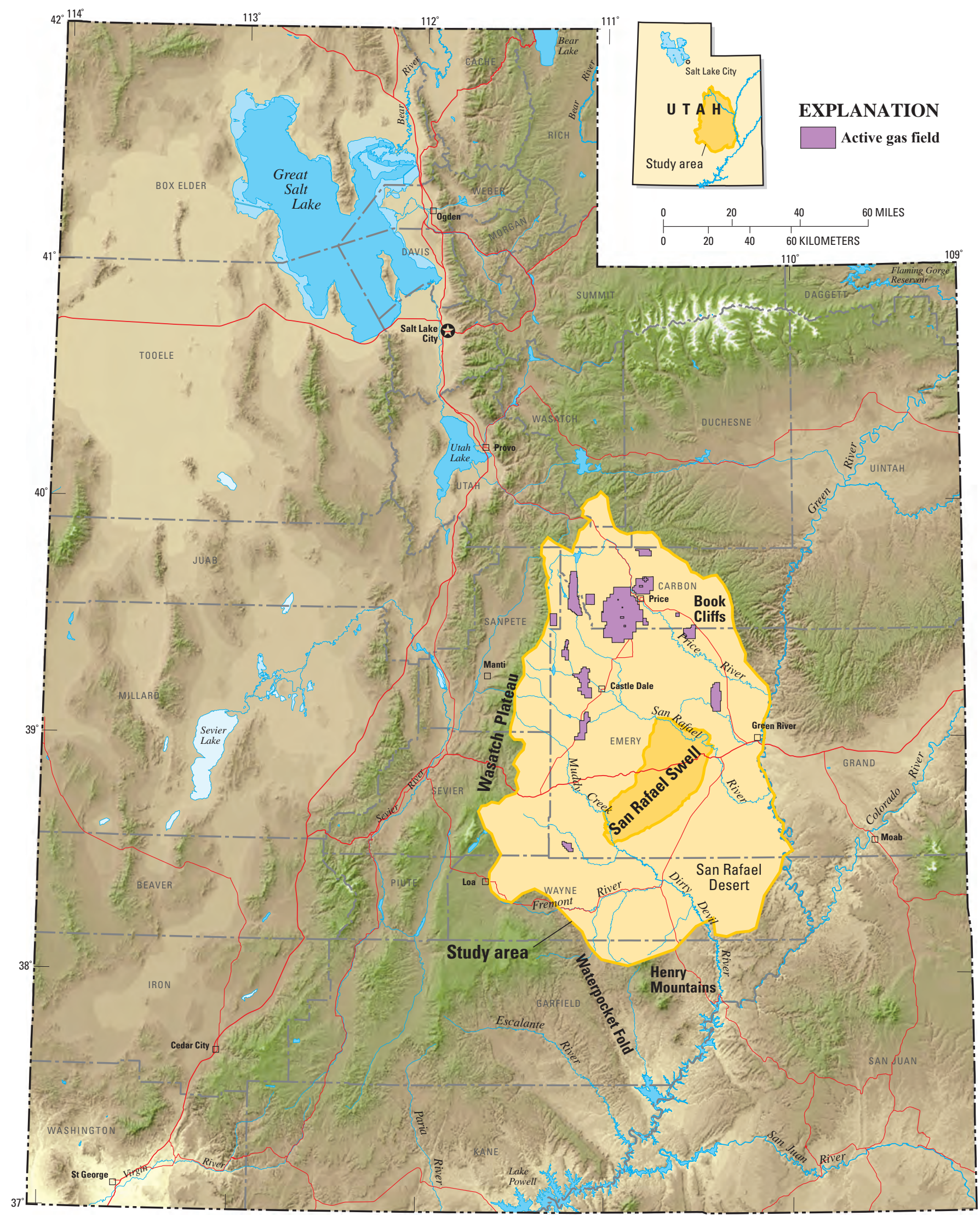

Figure 1. Location of geographic features and active gas fields in the Glen Canyon aquifer study area, Utah. 
flow areas, and potential changes in solute load to rivers, are not monitored. To address these regional-scale effects, the U.S. Geological Survey (USGS) in cooperation with the Utah Department of Natural Resources, Division of Oil, Gas, and Mining, developed a conceptual model of groundwater movement and transport of dissolved solids in the Glen Canyon aquifer. A numerical model that incorporates aquifer concepts was then constructed and used to simulate regionalscale effects. This study is limited to the Glen Canyon aquifer and no new hydrologic, chemical, or geologic data were collected during the study. Previous investigations and data provided by operators of injection wells were used to develop aquifer concepts.

\section{Purpose and Scope}

This report outlines the conceptual description and numerical simulation of a portion of the Glen Canyon aquifer that may be affected by injection of coal-bed methane production water (fig. 1). The numerical simulation includes ground-water flow and solute transport. The intended use of the numerical model is as a scoping tool to assess regional-scale effects of pressurized injection of coal-bed methane production water over a decadal time frame. Data limitations precluded the development of a detailed conceptual description or fully calibrated numerical model.

\section{Previous Studies}

Occurrence and movement of ground water in the Glen Canyon aquifer is described in several previous reports. The most recent report was a product of a region-wide study of the Upper Colorado River Basin in which Freethey and Cordy (1991) provided generalized area-wide estimates of hydraulic conductivity, porosity, and thickness of the Glen Canyon aquifer. Weiss (1987) simulated the flow of ground water in the Navajo Sandstone from the San Rafael Swell to the Green and Dirty Devil Rivers. This simulation confirmed that flow from the San Rafael Swell to the river canyons was plausible for the Navajo Sandstone part of the Glen Canyon aquifer. Weigel (1987) compiled hydrologic and lithologic properties derived from laboratory and field tests. Two bedrock aquifer studies in the early 1980s provided the conceptual basis for understanding ground-water flow in the aquifer (Hood and Danielson, 1981; Hood and Patterson, 1984). These two studies form the foundation for understanding the direction and rate of ground-water movement through the Navajo Sandstone in the vicinity of the San Rafael Swell.

\section{Acknowledgments}

The injection-well operators in the Ferron coal trend contributed knowledge and data. Personnel at the Utah Division of Oil, Gas, and Mining, especially Gilbert Hunt, provided information on injection rates, fluid concentrations, and projections for the future of the injection activities.

\section{Hydrogeology}

Ground-water movement and the geologic framework of the Glen Canyon aquifer within the study area have been described in previous studies. More recent data acquired during and after drilling of gas and petroleum-test wells has added knowledge about the flow system in areas where coalbed methane production water is being injected.

Maximum thickness of the Glen Canyon aquifer was estimated to range from 1,000 to $2,000 \mathrm{ft}$ in the southwestern part of the study area (Freethey and Cordy, 1991). Formation tops reported in Hood and Danielson (1981, tables 6 and 8), and Hood and Patterson (1984, tables 9 and 11) were used to create a generalized contour map depicting the pre-erosion altitude of the top of the Navajo Sandstone (fig. 2) and to estimate the thickness of each formation that is part of the Glen Canyon aquifer (figs. 3-5). Data indicate that the Navajo Sandstone accounts for 50 to 60 percent of the aquifer in the south, west, and northwest part of the study area, and about 25 percent of the aquifer in the northeast part. The Wingate Sandstone and the Kayenta Formation make up the remainder. As shown on the figures, data are sparse throughout large parts of the study area. For the numerical simulation, estimates of geometry and thickness of the Navajo Sandstone, Kayenta Formation, and Wingate Sandstone were required across the entire study area. As a consequence, contour lines represent a large amount of extrapolation and potentially represent a large amount of error. The contour lines in figures 2-5 are for scoping purposes only and should not be used for other types of analysis.

All or parts of the Navajo Sandstone, Kayenta Formation, and Wingate Sandstone are exposed at the perimeter of the San Rafael Swell, the Circle Cliffs Uplift, and where the Muddy, Dirty Devil, San Rafael, and Green Rivers have cut down into the west side of the Monument Uplift (fig. 6). The formations on the west side of the San Rafael Swell dip to the west and reach depths of several thousand feet below sea level under the Wasatch Plateau. On the northeast flank of the swell the formations dip to the northeast and are deeply buried beneath the Book Cliffs. To the southeast of the San Rafael Swell the formations are essentially flat-lying and widely exposed.

The Glen Canyon aquifer within the study area is deformed, faulted, and fractured owing principally to regionaland local-scale tectonic processes. Most faults on the east side of the study area are oriented northwest to southeast, perpendicular to the orientation of the major anticlinal uplifts. Faults on the western edge of the study area are oriented north-south. It is not known if fluid movement within the Glen Canyon aquifer is substantially influenced by the presence or orientation of these faults.

Aquifer properties of the Glen Canyon aquifer vary most from south to north. On the basis of a small number of surface samples listed in Weigel (1987, table 5), aquifer porosity generally is greater than 0.2 in the southern half of the study area and less than 0.2 in the northern half (Freethey and Cordy, 1991, fig. 30). An approximate overall distribution of porosity 


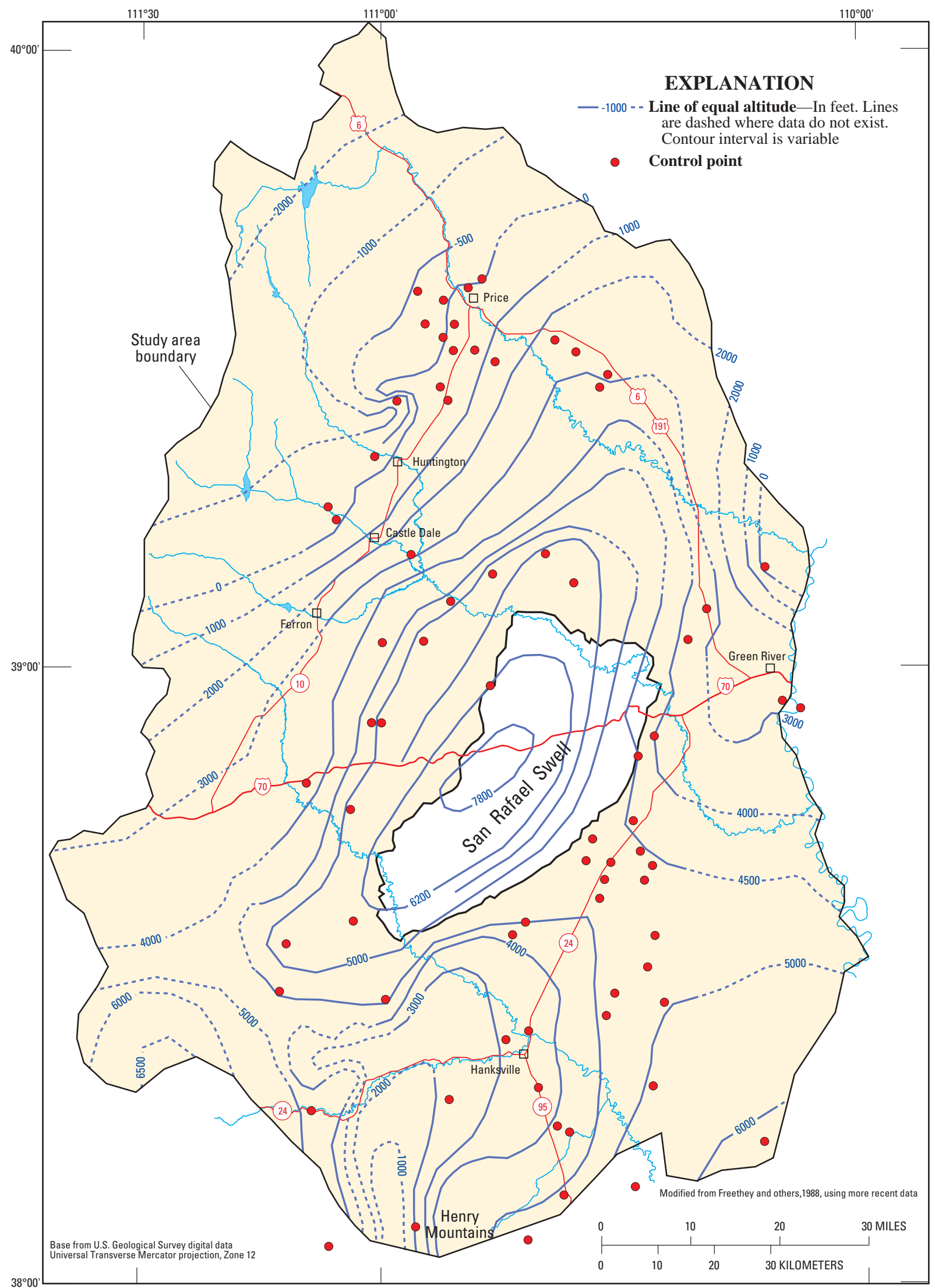

Figure 2. Approximate pre-erosion altitude of the top of the Navajo Sandstone in the Glen Canyon aquifer study area, Utah. 


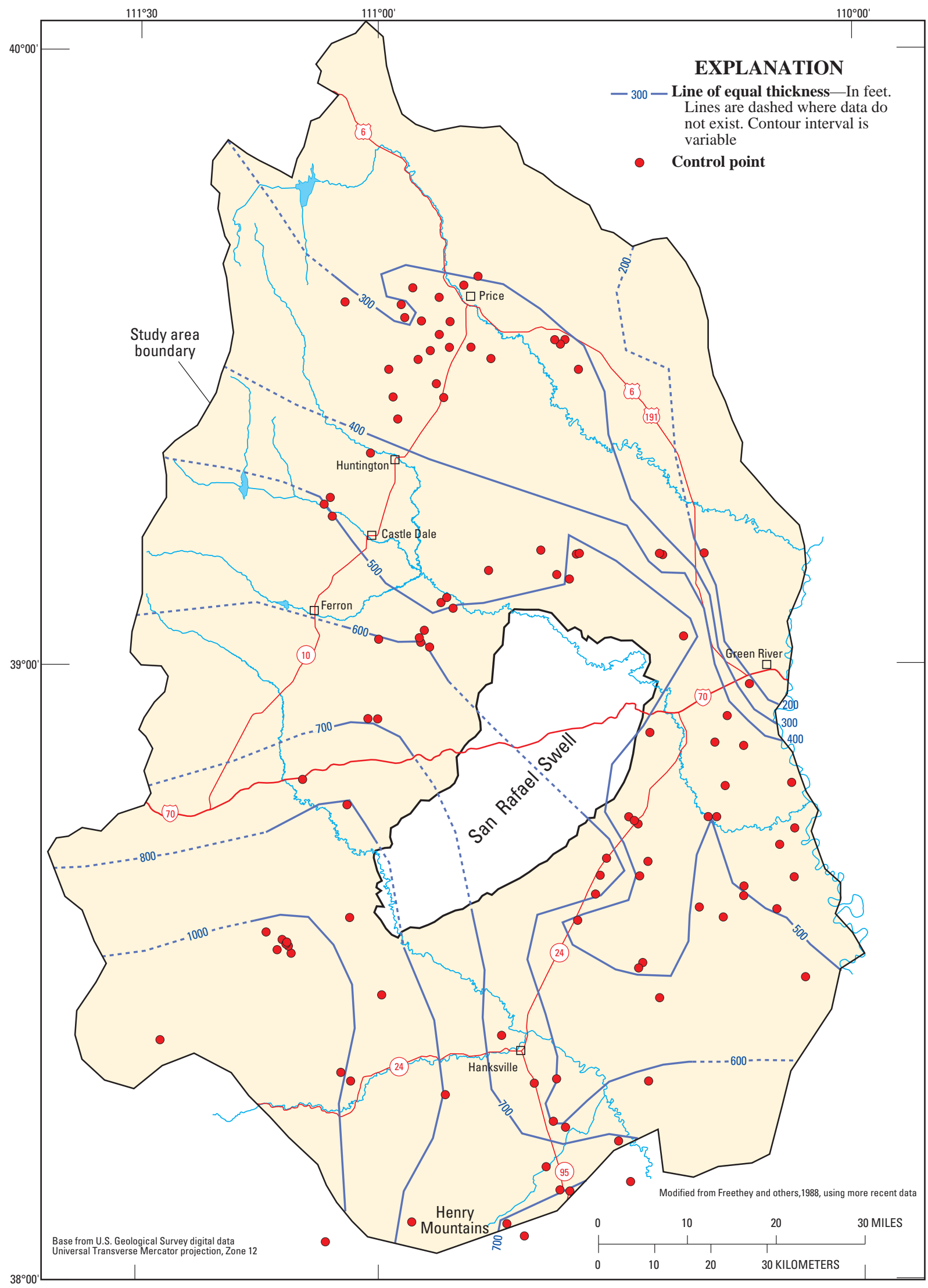

Figure 3. Approximate pre-erosion thickness of the Navajo Sandstone in the Glen Canyon aquifer study area, Utah. 


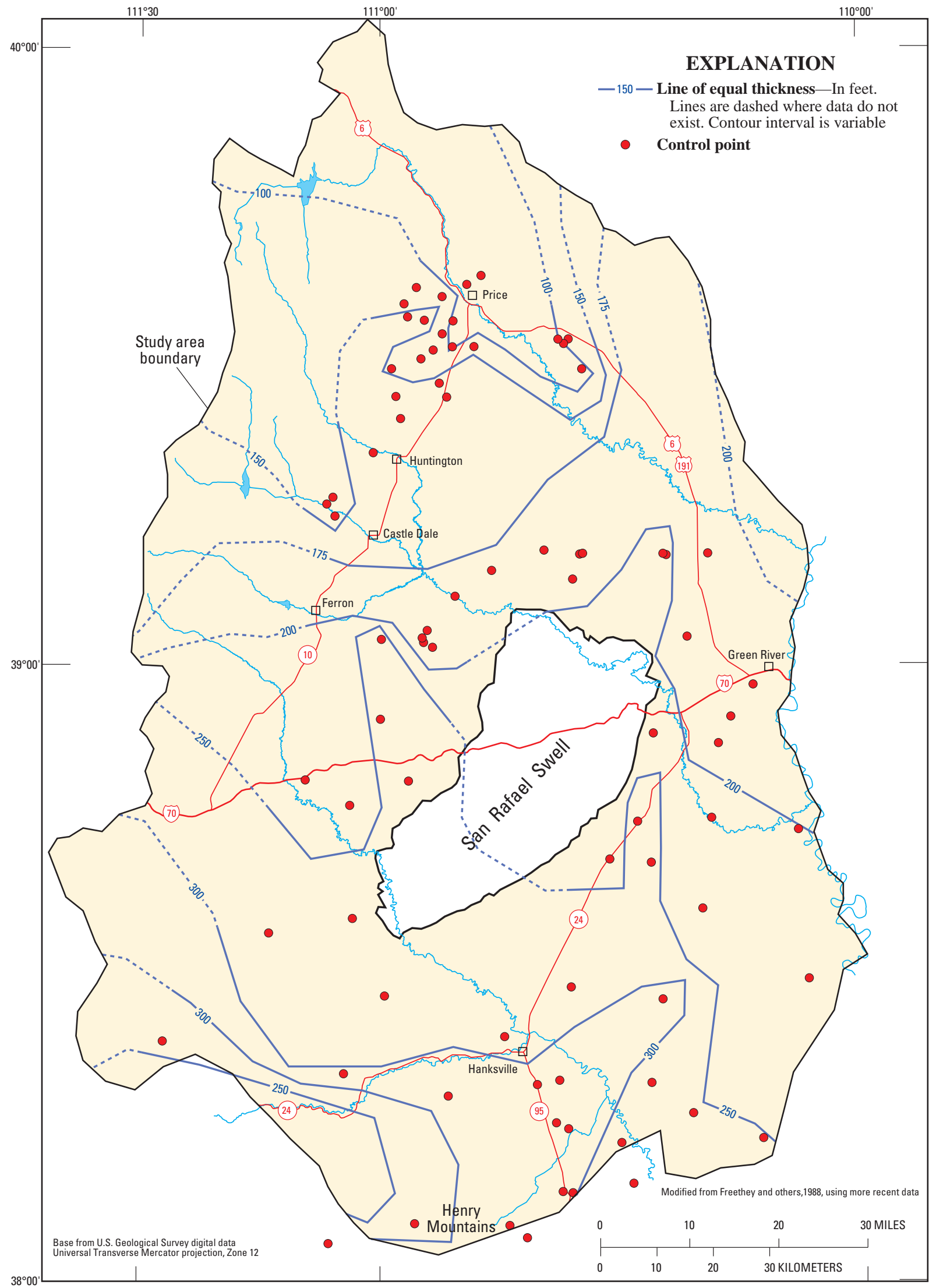

Figure 4. Approximate pre-erosion thickness of the Kayenta Formation in the Glen Canyon aquifer study area, Utah. 


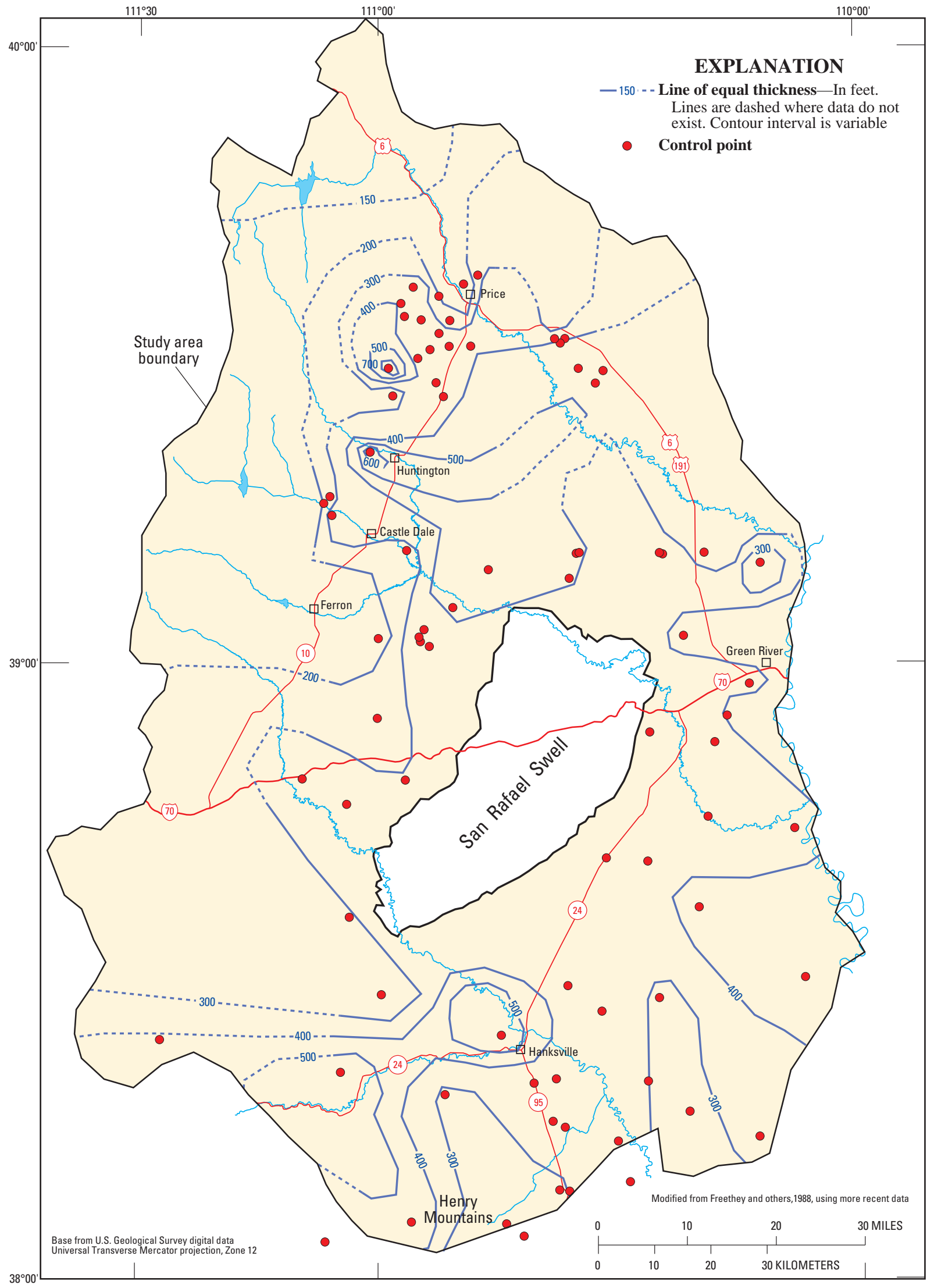

Figure 5. Approximate pre-erosion thickness of the Wingate Sandstone in the Glen Canyon aquifer study area, Utah. 


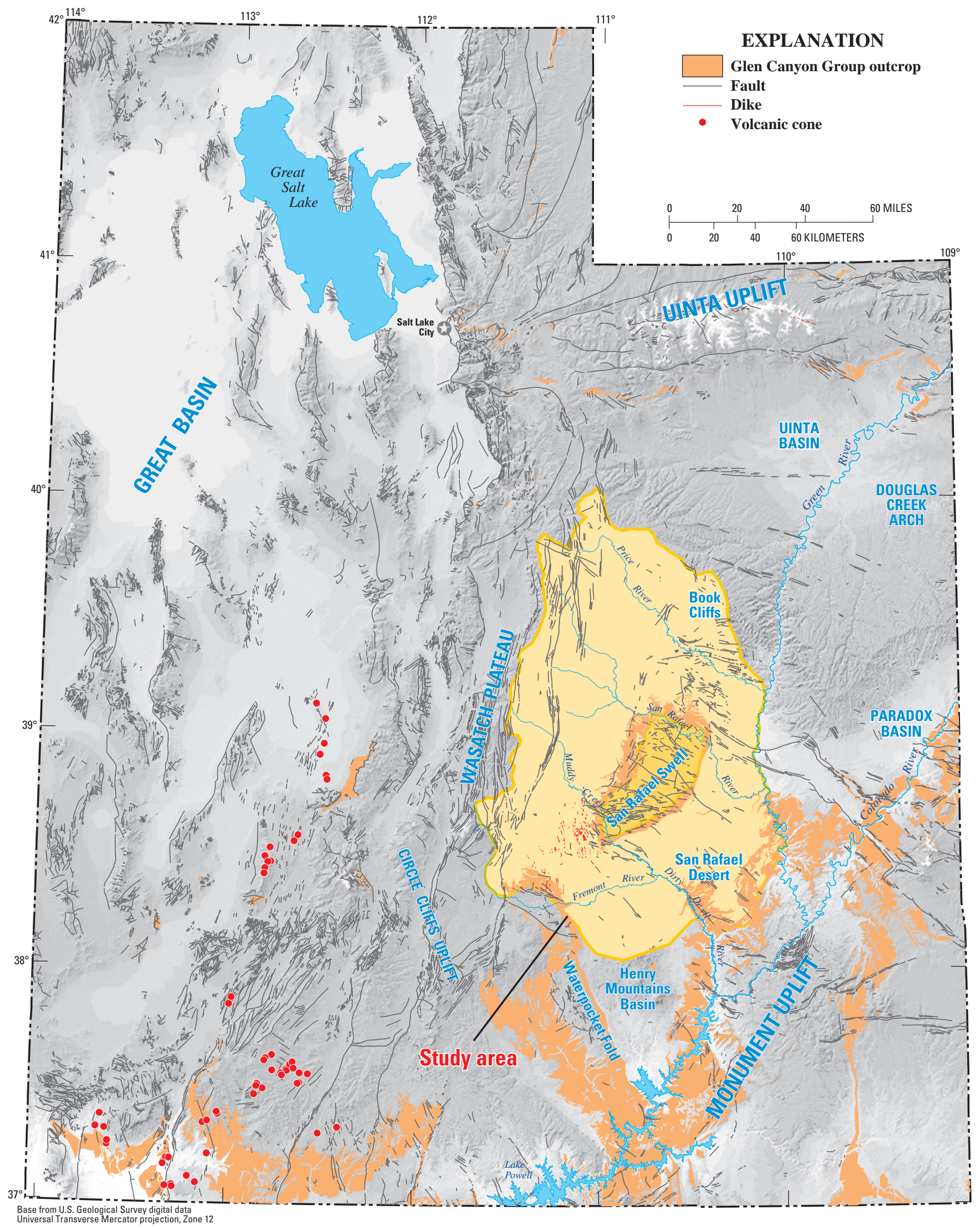

Figure 6. Outcrop areas for the Navajo Sandstone, Kayenta Formation, and Wingate Sandstone, and structural features in and around the Glen Canyon aquifer study area, Utah. 
for the Glen Canyon aquifer study area is shown in figure 7a. The distribution of hydraulic conductivity in the Glen Canyon aquifer is similar to porosity, with values of about 1 to $2 \mathrm{ft} / \mathrm{d}$ south of the San Rafael Swell and values of less than about $0.1 \mathrm{ft} / \mathrm{d}$ in the northern half of the study area where the aquifer is buried beneath younger formations. The overall distribution of hydraulic conductivity for the Glen Canyon aquifer estimated by using data from Weigel (1987, tables 4 and 5) is shown in figure $7 \mathrm{~b}$. Values of hydraulic conductivity were measured or estimated from surface samples, drill-stem tests, aquifer tests, and specific-capacity tests and range from 0.00003 to $180 \mathrm{ft} / \mathrm{d}$ (Weigel, 1987). The Navajo Sandstone is a well-sorted, cross-bedded, poorly cemented eolian deposit. The Kayenta Formation is a poorly sorted, multilayered, well-cemented fluvial sandstone with occasional mudstone layers. The Wingate Sandstone is a well-sorted, well-cemented, massive eolian deposit. Because hydraulic conductivity generally decreases with decreasing grain size, decreased sorting, depth of burial, and increased cementation, values for the Navajo Sandstone likely are larger than values for the Kayenta Formation or the Wingate Sandstone. Transmissivity values for the Glen Canyon aquifer reflect the hydraulic-conductivity distribution. Values of about $2,000 \mathrm{ft}^{2} / \mathrm{d}$ are estimated for the southwestern part of the area where the aquifer is thickest, and less than $100 \mathrm{ft}^{2} / \mathrm{d}$ for the northwestern part (Freethey and Cordy, 1991, fig. 50).

\section{Conceptualization of Flow and Solute Transport}

The Glen Canyon aquifer within the study area is conceptualized in two parts - an active area of ground-water flow and solute transport that exists between recharge and discharge locations, and an area of little or negligible groundwater flow north of Price and beneath the Wasatch Plateau (figs. 6 and 8). Flow and transport in the active area was presumed to be in equilibrium, or "steady state," prior to injection of coal-bed methane production water. This means that water and solute entering and exiting the active aquifer area are equal. The post-injection transient conditions represent variations from the steady-state condition in response to influx of water and mass of solutes associated with the disposal of coal-bed methane production water.

\section{Recharge, Movement, and Discharge of Ground Water}

Ground-water recharge to the Glen Canyon aquifer is primarily from precipitation that infiltrates into the sandstones. Minor recharge may occur where perennial rivers traverse outcrops of Navajo or Wingate Sandstone creating downward percolation. Hood and Patterson (1984) estimated recharge at the perimeter of the San Rafael Swell into the Navajo Sandstone to be about 3,000 acre-ft/yr (table 1). Hood and
Danielson (1981, p. 32) estimated average recharge to Navajo outcrops in the Waterpocket Fold and along the Fremont River to be about 7,000 acre-ft/yr. Some recharge also may occur in the San Rafael Desert where the Navajo Sandstone is covered with sand. The sand stores precipitation and allows for slow infiltration. Minor additional recharge to the Navajo Sandstone probably takes place in areas where the overlying Carmel Formation is thin or absent, and on the flanks of the Henry Mountains. Total recharge in these areas is estimated to be less than 1,000 acre-ft/yr (table 1).

No estimates of recharge to the Wingate Sandstone or the Kayenta Formation were made by Hood and Danielson (1981). The Wingate is less extensively exposed and generally less porous at surface exposures than the Navajo Sandstone. On the basis of those attributes, recharge to the Wingate is estimated at about one-half of the Navajo recharge (table 1). Recharge to the Wingate is spatially distributed according to surface exposure. Recharge directly into the Kayenta Formation likely is relatively minor because of the presence of many more interbedded fine-grained deposits than in the Navajo or Wingate Sandstones.

Water-level measurements in wells, and altitudes of springs and land surfaces along hydraulically connected rivers (Hood and Danielson, 1981; Hood and Patterson, 1984; Weiss, 1987 ) indicate that ground water flows from recharge areas at 1) the perimeter of the San Rafael Swell, 2) the Waterpocket Fold, and 3) the Henry Mountains, to discharge areas in the canyons of the Muddy, Dirty Devil, San Rafael, and Green Rivers (fig. 8). This concept was tested for the Navajo Sandstone and determined to be plausible (Weiss, 1987).

The northwest area of the Glen Canyon aquifer (west of Ferron, north of Price, and beneath the Wasatch Plateau, fig. 8) is conceptualized as having little or negligible groundwater movement. The reason for this is threefold. The aquifer dips to the west and is several thousand feet below land surface; this has created geometry similar to a bowl or pool. Deep burial suggests little or no recharge, and ground water in the bowl is dense brine (Freethey and others, 1988, fig. 19). The combination of structure, lack of recharge, and density supports the concept of essentially no ground-water movement in the northwest area. Active ground-water flow occurs generally between the recharge areas along the western perimeter of the San Rafael Swell to the north and south, and the discharge areas along the Muddy, Dirty Devil, San Rafael, and Green Rivers. At steady-state conditions, hydrologic interaction between the areas of active and little or negligible ground-water flow is most likely insignificant.

As stated in Hood and Danielson (1981) and Hood and Patterson (1984), discharge from the Glen Canyon aquifer is mainly diffuse seepage to rivers, to seeps and springs, by evapotranspiration, and by minor amounts of withdrawals from wells. Measuring and estimating the volume of discharge associated with each of these processes is difficult. Phreatophytes grow where springs and seeps discharge ground water and also along perennial rivers regardless of whether or not the river reach is receiving ground-water inflow or if it is recharging an underlying aquifer. Hood and Danielson (1981) 


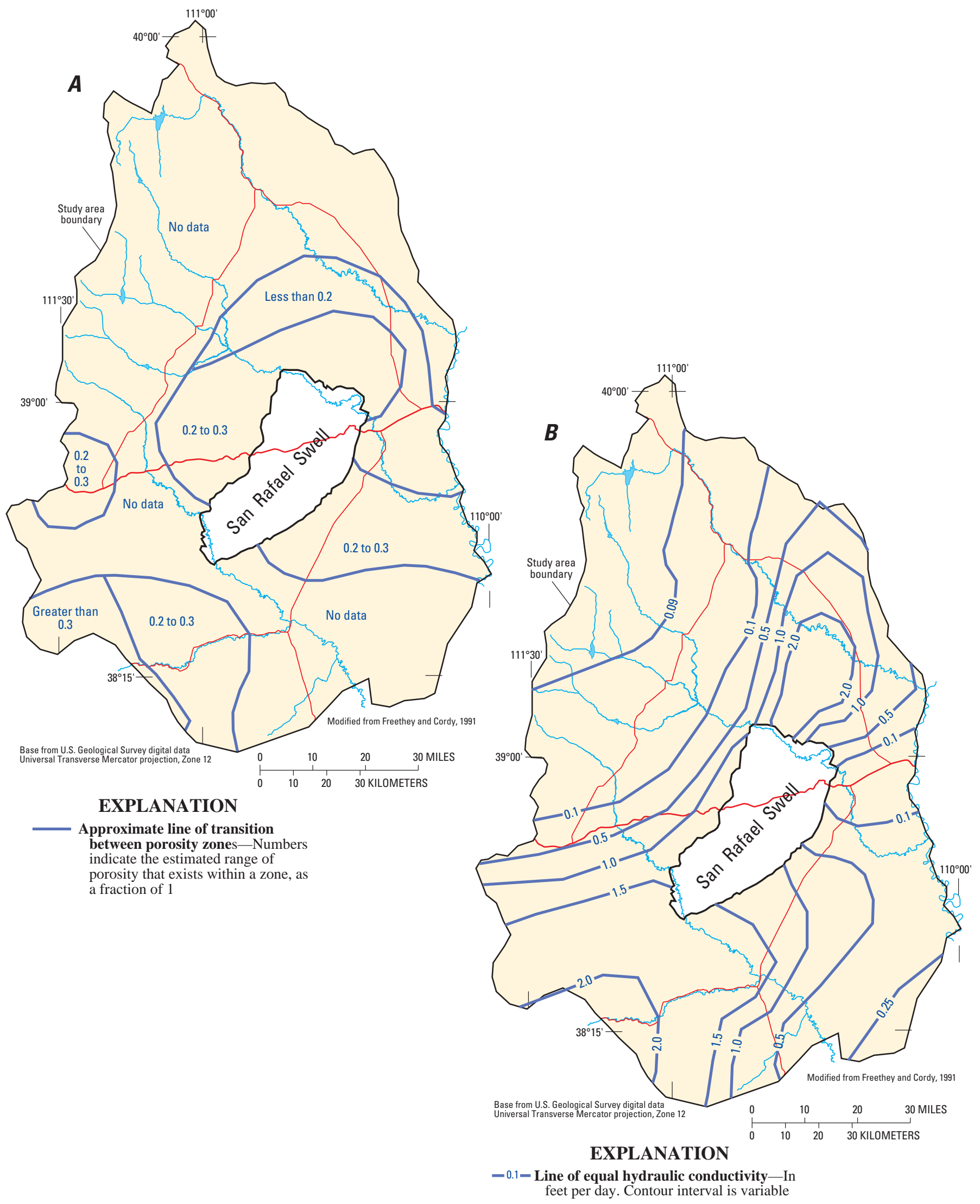

Figure 7. Estimated distribution of $A$, porosity and $B$, hydraulic conductivity in the Glen Canyon aquifer study area, Utah. 
Table 1. Conceptual ground-water budget for the active flow areas in the Glen Canyon aquifer study area, Utah.

\begin{tabular}{|c|c|c|c|}
\hline Location & Formation & $\begin{array}{c}\text { Recharge, in } \\
\text { acre-feet per } \\
\text { year }\end{array}$ & $\begin{array}{l}\text { Discharge, in acre- } \\
\text { feet per year }\end{array}$ \\
\hline \multirow[t]{3}{*}{ San Rafael Swell—north, west, and south sides } & Navajo & 23,000 & \\
\hline & Kayenta & small & \\
\hline & Wingate & 1,000 & \\
\hline San Rafael Swell—east side & All ${ }^{1}$ & small & \\
\hline \multirow{3}{*}{ Waterpocket Fold and Fremont River } & Kayenta & small & \\
\hline & Wingate & 3,000 & \\
\hline & $\mathrm{All}^{1}$ & & 500 \\
\hline San Rafael Desert & Navajo & 500 & \\
\hline \multirow{2}{*}{$\begin{array}{l}\text { Mouth of San Rafael River and along the Green River (includes seepage to streams and } \\
\text { evapotranspiration) }\end{array}$} & Kayenta & & small \\
\hline & Wingate & & 500 \\
\hline \multirow[t]{3}{*}{ Dirty Devil River (includes seepage to stream and evapotranspiration) } & Navajo & & ${ }^{4} 5,000$ \\
\hline & Kayenta & & 1,000 \\
\hline & Wingate & & 2,500 \\
\hline Muddy Creek at edge of Swell (includes seepage to stream and evapotranspiration) & $\mathrm{All}^{1}$ & & 1,000 \\
\hline San Rafael River at edge of Swell (includes seepage to stream and evapotranspiration) & $\mathrm{All}^{1}$ & & ${ }^{2} 1,000$ \\
\hline Evapotranspiration directly from Glen Canyon aquifer & $\mathrm{All}^{1}$ & & 1,000 \\
\hline Pumping from Glen Canyon aquifer throughout study area & All $^{1}$ & & 500 \\
\hline
\end{tabular}

1 Indicates that the amount is for all formations of the Glen Canyon aquifer, which includes the Navajo Sandstone, Kayenta Formation, and Wingate Sandstone.

2 From Hood and Patterson, 1984, table 6.

3 From Hood and Danielson, 1981, p. 32.

4 From Hood and Danielson, 1981, p. 43.

and Hood and Patterson (1984) surmised that the largest component of discharge is likely evaporation and transpiration. The estimates shown in table 1 are based on observations of phreatophyte extent, stream baseflows, seeps and springs, and number of wells. There is a high degree of uncertainty associated with these estimates.

\section{Water Quality}

The quality and density of water in the Glen Canyon aquifer in the study area varies. Freethey and others (1988) reported the dissolved-solids concentration in the aquifer beneath the Wasatch Plateau to be higher than $35,000 \mathrm{mg} / \mathrm{L}$ (fig. 9a). More recent information collected by gas producers indicates concentrations greater than $100,000 \mathrm{mg} / \mathrm{L}$, and the primary constituents are sodium and chloride. Dissolvedsolids concentration in ground water in areas where the formations are exposed is less than $1,000 \mathrm{mg} / \mathrm{L}$, and the primary constituents are calcium, magnesium, and bicarbonate. Where precipitation infiltrates the Carmel Formation before recharging the Glen Canyon aquifer, the primary constituents are calcium and sulfate. For the Glen Canyon aquifer, dissolved-solids concentration typically increases with depth of burial (Freethey and others, 1988, fig. 19). Dissolved-solids concentration in the Glen Canyon aquifer in the area south of Price, Utah, increases from about 3,000 mg/L to greater than $100,000 \mathrm{mg} / \mathrm{L}$ in a horizontal distance of less than $5 \mathrm{mi}$, as depth of burial increases by about 1,500 ft.

On the basis of dissolved-solids concentrations reported in Freethey and others (1988) and from samples analyzed by injection-well operators, density of ground water in the Glen Canyon aquifer is estimated to be as high as $73 \mathrm{lbs} / \mathrm{ft}^{3}$ where the aquifer is buried under the Wasatch Plateau and about $62 \mathrm{lbs} / \mathrm{ft}^{3}$ in areas where the same formations are exposed and precipitation recharges the system. 


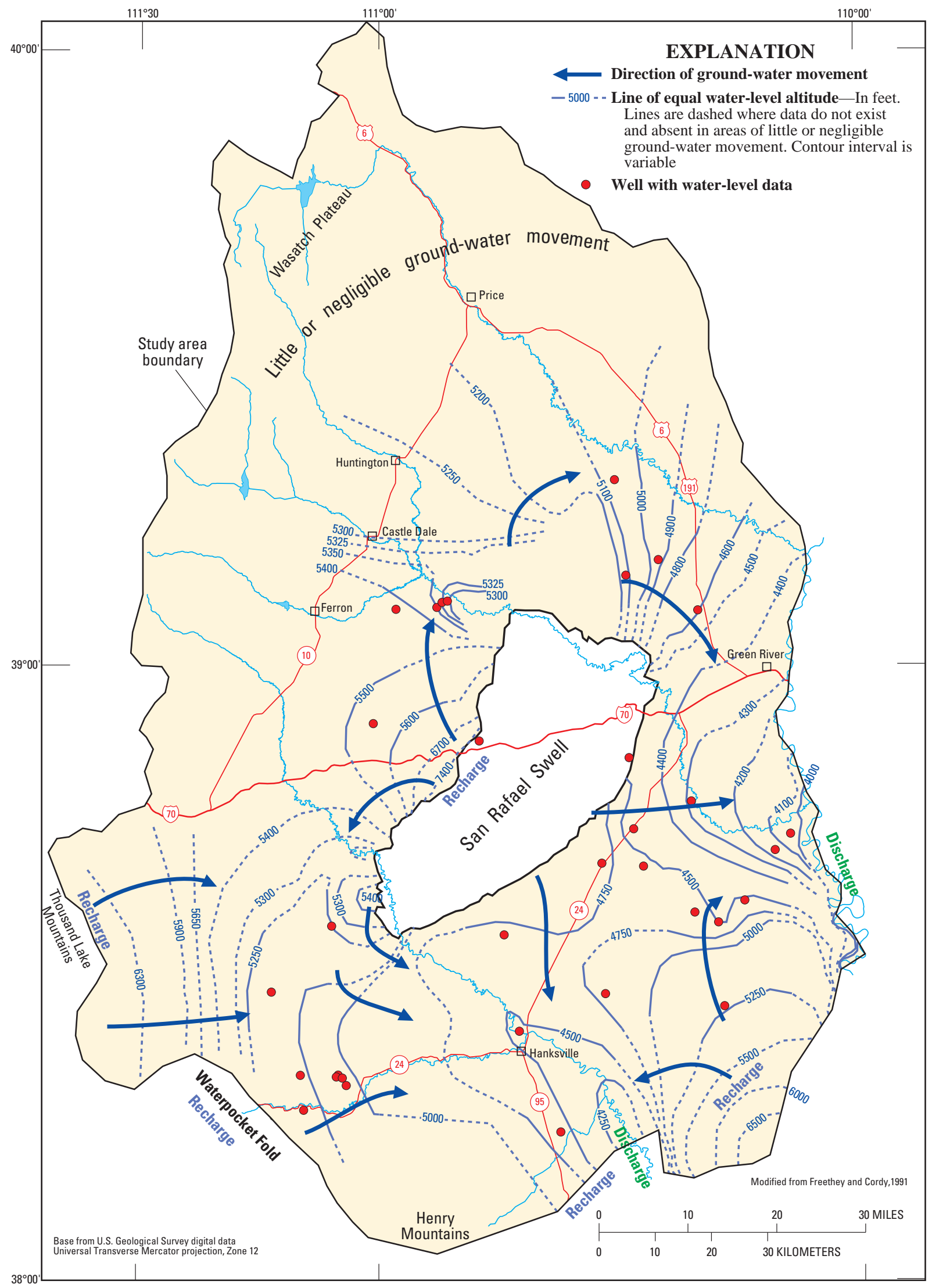

Figure 8. Estimated distribution of water levels and assumed direction of ground-water movement in the Glen Canyon aquifer study area, Utah. 

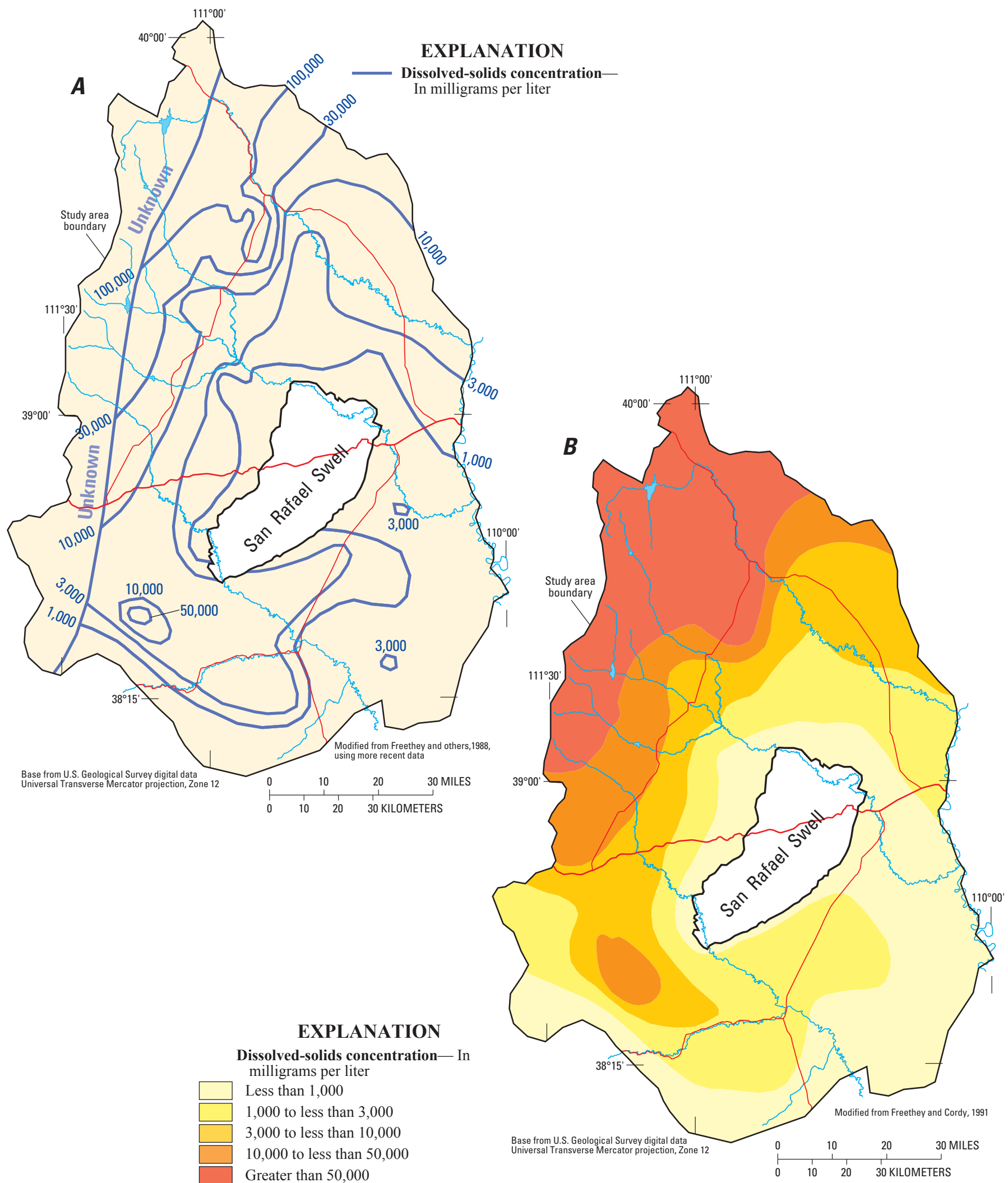

Figure 9. A, estimated dissolved-solids concentration contours and $B$, a generalized dissolved-solids concentration distribution for ground water in the Glen Canyon aquifer study area, Utah. 
The amounts of fresh and saline water stored in the aquifer were estimated by generalizing and extending the dissolved-solids concentration contours shown on fig. 9a into a water-quality distribution for the entire aquifer (fig. 9b). Using thickness and porosity, and assuming the aquifer is fully saturated, the calculated volume of water stored in the area where dissolved-solids concentration is less than $3,000 \mathrm{mg} / \mathrm{L}$ is about 400 million acre-ft. The amount of dissolved solids in the fresher water is about 1 billion tons. The volume of water stored in the area where dissolved-solids concentration is greater than $3,000 \mathrm{mg} / \mathrm{L}$, assuming full saturation, is about 300 million acre-ft. The amount of dissolved solids in the more saline water is about 16 billion tons. The $3,000-\mathrm{mg} / \mathrm{L}$ contour is also a rough delineation between the relatively active fresher-water and inactive more saline-water areas of the aquifer.

\section{Stress from Development}

Prior to 1994, stresses imposed on the Glen Canyon aquifer are presumed to have been negligible. Pumping rates for stock watering, mining operations, and private supplies probably were less than 500 acre-ft/yr. In 1994, coal-bed methane producers began pressurized injection of production water from relatively shallow coal-bed methane gas production wells into the much deeper Glen Canyon aquifer. This initiated a net addition of flow and mass of solutes to the aquifer and the onset of transient flow and transport conditions. Dissolved-solids concentration in the injected water ranged from about 5,000 to $40,000 \mathrm{mg} / \mathrm{L}$. Injection takes place in the northwest area of the aquifer where prior to injection there was likely little or negligible ground-water movement. The total amount of water injected from 1994 to 2004 was about 25,000 acre-feet (table 2). Maximum injection occurred in 2001. It is estimated that injection will diminish and likely cease by 2010 (Gilbert Hunt, Utah Division of Oil, Gas, and Mining, written commun., 2004).

Increased recharge represents less that 0.004 percent of the total water stored in the aquifer (estimated at 700 million acre$\mathrm{ft}$ ). Total salt added to the aquifer from injection (375,000 tons from 1994 to 2003) represents about 0.02 percent of the solute already in the aquifer. Although injection is minor when compared to the total volume of water and mass of solute in the aquifer, it is on the order of 25 percent of the natural steady-state flow in the active flow area of the aquifer (see table 1). To better understand how pressurized injection of coal-bed methane production water may affect the regionalscale interaction between different flow regimes of the Glen Canyon aquifer, a numerical model was constructed.

\section{Numerical Simulation}

SUTRA (Voss and Provost, 2002), a three-dimensional finite-element model, was used to simulate ground-water flow and transport of solutes in the Glen Canyon aquifer. Required input parameters include permeability, molecular diffusion, longitudinal and transverse dispersivity, effective porosity, and a coefficient that converts dissolved-solids concentration to fluid density. SUTRA incorporates the effects of fluid density and pressure in the solution of flow and transport equations. The model approximates injection of moderately-to-highly saline water into the aquifer at various locations and depths. Sources of solutes from recharge and injected water are simulated; areas of existing brine water $(>35,000 \mathrm{mg} / \mathrm{L}$ dissolved-solids concentration) are specified, but the sources of that brine are unknown and therefore not simulated. The model simulates the conservative transport of solutes in ground water; non-conservative dissolution or adsorption of solutes is not simulated. The entire aquifer area is simulated as fully saturated and confined, which is a simplification for recharge and discharge areas, where water-table conditions exist. A graphical user interface that supports SUTRA (Winston and Voss, 2004) was used in conjunction with ArgusONE to develop the model. The model is constructed using the International System (SI) units of measurement; SI units are more convenient for expressing SUTRA input parameters. English units presented in conceptual discussions were converted. The model is available to the public from the USGS Utah Water Science Center.

The model described in this report is based largely on information from previous investigations. No additional field data were collected specifically for this study. The numerical model is not intended to predict water-level, pressure, or concentration changes at specific locations as a result of imposed stresses. The purpose of the model is to improve understanding of solute transport through the Glen Canyon aquifer on a regional scale over a decadal time frame, and

Table 2. Amount and quality of water injected into the Glen Canyon aquifer study area, Utah.

[Source: Gilbert Hunt, Utah Department of Natural Resources, Division of Oil, Gas, and Mining, written commun., 2004. Total amount injected from 1994 through 2004 is 24,903 acre-feet]

\begin{tabular}{|cccc}
\hline Year & $\begin{array}{c}\text { Amount } \\
\text { injected } \\
\text { (acre-feet) }\end{array}$ & $\begin{array}{c}\text { Range of } \\
\text { dissolved-solids } \\
\text { concentration in } \\
\text { injected water } \\
\text { (milligrams per liter) }\end{array}$ & $\begin{array}{c}\text { Number of } \\
\text { injection } \\
\text { wells }\end{array}$ \\
\hline 1994 & 77 & 6,459 & 1 \\
\hline 1995 & 240 & 8,025 & 1 \\
\hline 1996 & 410 & $7,643-18,911$ & 4 \\
\hline 1997 & 1,145 & $6,440-25,500$ & 7 \\
\hline 1998 & 2,317 & $6,092-27,052$ & 10 \\
\hline 1999 & 3,230 & $4,824-19,365$ & 12 \\
\hline 2000 & 3,899 & $5,649-30,606$ & 15 \\
\hline 2001 & 4,294 & $5,301-30,806$ & 19 \\
\hline 2002 & 3,908 & $10,167-36,331$ & 20 \\
\hline 2003 & 3,467 & $10,000-42,042$ & 23 \\
\hline 2004 & 1,916 & Not reported & 21 \\
\hline
\end{tabular}


provide a scoping-level tool to assess regional scale effects that could result from injection of coal-bed methane production water. Hydrologic data for large parts of the study area are not available. The limited availability of water-level, water-quality, and discharge data prohibit the development of an adequately constrained, reliably calibrated model.

\section{Model Construction}

To represent the hydrologic system of the Glen Canyon aquifer study area, specific characteristics are assigned to each of the model nodes. These characteristics include 1) geometry of the aquifer system, 2) conditions at the boundaries of the aquifer system, 3) aquifer properties, and 4) dissolved-solids concentration in water from the aquifer. The volume and dissolved-solids concentration of the water injected into the aquifer also are specified.

To manage the complex parameterization required for fluid pressure, solute transport, and density, simpler versions of aquifer conditions were initially considered. At the outset model construction and simulation included only fluid flow; then solute transport and fluid density were incorporated. This made it easier to gage the effects of adjusting model parameters, maintain numerical stability, and refine initial conditions.

\section{Aquifer Geometry}

The model domain is vertically discretized into three layers, one for each of the geologic units in the Glen Canyon aquifer - the Navajo Sandstone, Kayenta Formation, and Wingate Sandstone. The model domain was constructed to approximate the areal extent of the aquifer and consists of 10,701 quadrilateral finite elements (four-sided blocks). The quadrilateral elements form 10,912 nodes at points where elements connect at their corners (fig. 10a and b). The structure of SUTRA does not allow for inactive elements and nodes within the model domain. In some places the domain covers areas where the aquifer does not exist (San Rafael Swell) or extends beyond the lateral extent of the aquifer. Those areas were assigned an extremely small hydraulicconductivity values to simulate no-flow conditions.

The geometry of the aquifer in the simulation was approximated by the contour map depicting the altitude of the top of the Navajo Sandstone and the isopach maps depicting the thickness of the geological units that make up the aquifer (figs. 2-5). Data extracted from interpolations of these maps were used to assign altitudes for each node (and element) in the model domain.

\section{Aquifer Boundaries}

The lateral boundaries described previously are represented in the simulation using no-flow boundaries. These boundaries simulate ground- and surface-water divides and are sufficiently distant from the injection wells that they have little influence on numerical results. The top and bottom of the Glen Canyon aquifer are also simulated as no-flow boundaries.
The bottom of the aquifer is defined as the geologic contact between the Wingate Sandstone and the underlying Chinle Formation. The Chinle Formation is a thick, continuous shale layer with low permeability and was considered a barrier for purposes of flow and transport simulation. The lithologic character of the Carmel Formation overlying the Navajo Sandstone is sufficiently fine-grained to also simulate it as a no-flow boundary.

Where the Carmel Formation has been eroded away and geologic units of the Glen Canyon aquifer crop out, the no-flow boundary is not accurate. This situation exists along rivers and at the perimeter of the San Rafael Swell. SUTRA can simulate water-table conditions (top boundary as a free surface) only when the unsaturated flow option is used. This was not done because describing unsaturated flow conditions requires the estimation of additional unquantified aquifer properties and creates non-linearity in the numerical simulation.

To simulate water movement within the aquifer, specifiedsource and specified-pressure boundaries were used. Where the aquifer is cropped out and along the surface contact between the Navajo Sandstone and Carmel Formation, the top of the model domain is simulated as a specified-source boundary. The boundary simulates areal recharge and the distribution is shown in figure 11; amounts correspond to the active-flow area values listed in table 1 . The surface contact between the Navajo and Carmel is included as a fluid source because some water transfer was observed to occur in a similar geologic setting on the east side of Zion National Park (Cordy and others, 1993). Specified-pressure boundaries simulate springs and the San Rafael, Muddy, Dirty Devil, and Green Rivers (fig. 11). Evapotranspiration is estimated to occur at the same locations where ground-water discharge to springs and rivers occurs and is simulated as part of the specified-pressure boundaries. Discharge to pumping wells in the Glen Canyon aquifer is not simulated because pumping is only about 3 percent of the total estimated discharge from the aquifer (table 1). Pressurized injection of production water is simulated as a fluid source to the Navajo Sandstone at the locations of the injection.

\section{Aquifer Properties}

Aquifer properties needed for the simulation include permeability, direction and amount of anisotropy, effective porosity, solid-matrix compressibility, longitudinal dispersivity, and transverse dispersivity. The initial value and distribution of permeability was specified on the basis of hydraulic conductivity for the Glen Canyon aquifer (fig. 7b). Conductivities for the Glen Canyon aquifer were converted to permeability using the following properties: 1) fluid viscosity of $0.001 \mathrm{~kg} / \mathrm{ms}$, 2) fluid density of $998.2 \mathrm{~kg} / \mathrm{m}^{3}$, and 3) acceleration of gravity of $9.81 \mathrm{~m} / \mathrm{s}^{2}$. The converted permeabilities were used as initial values for model layer 1 , which simulates the Navajo Sandstone. Initial values assigned to the Kayenta Formation (layer 2) were scaled at 50 percent of the Navajo Sandstone values. Values assigned to the Wingate Sandstone were scaled at 90 percent of Navajo Sandstone 


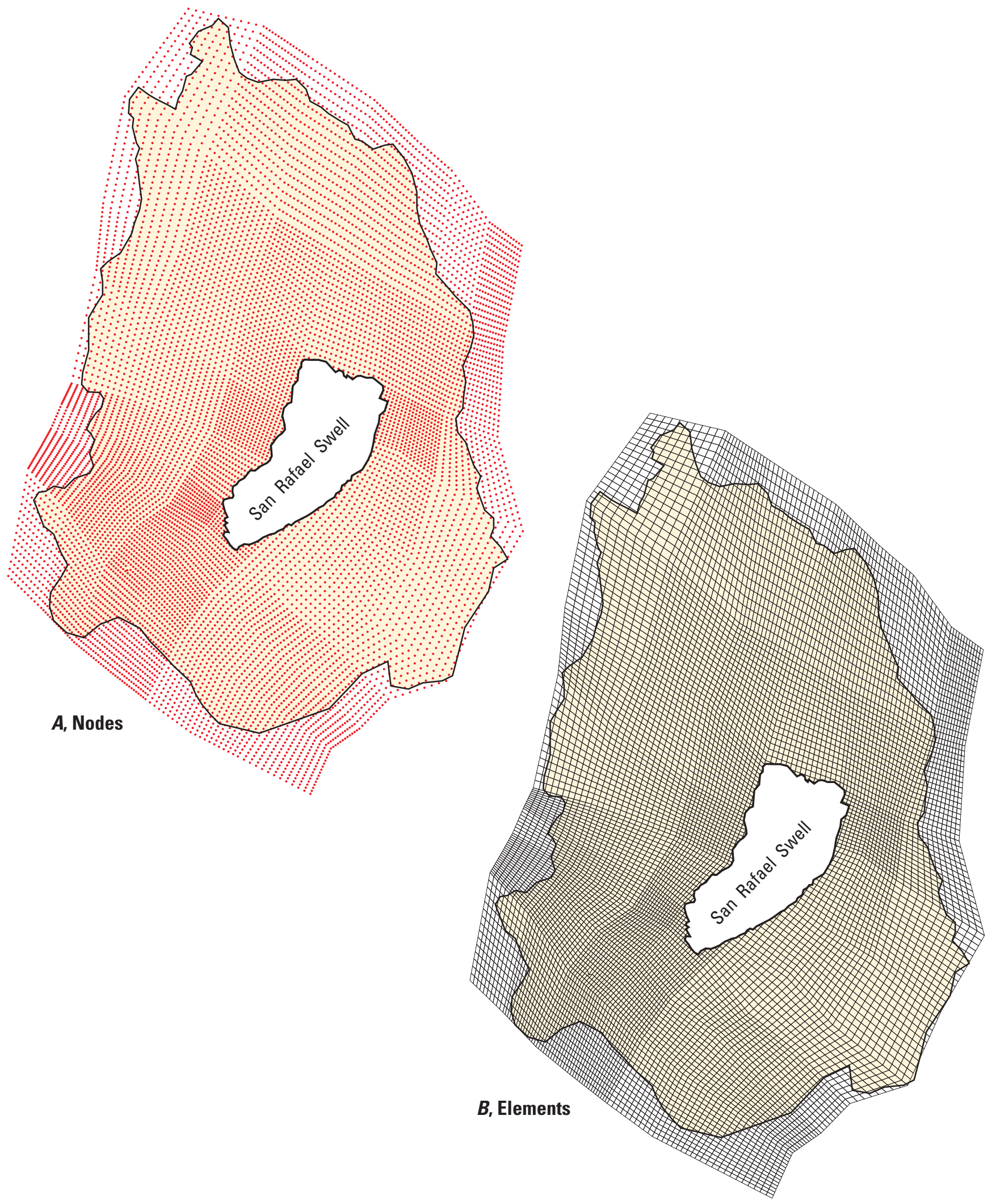

Figure 10. Model $A$, nodes and $B$, elements used to simulate ground-water flow and solute transport in the Glen Canyon aquifer study area, Utah. 


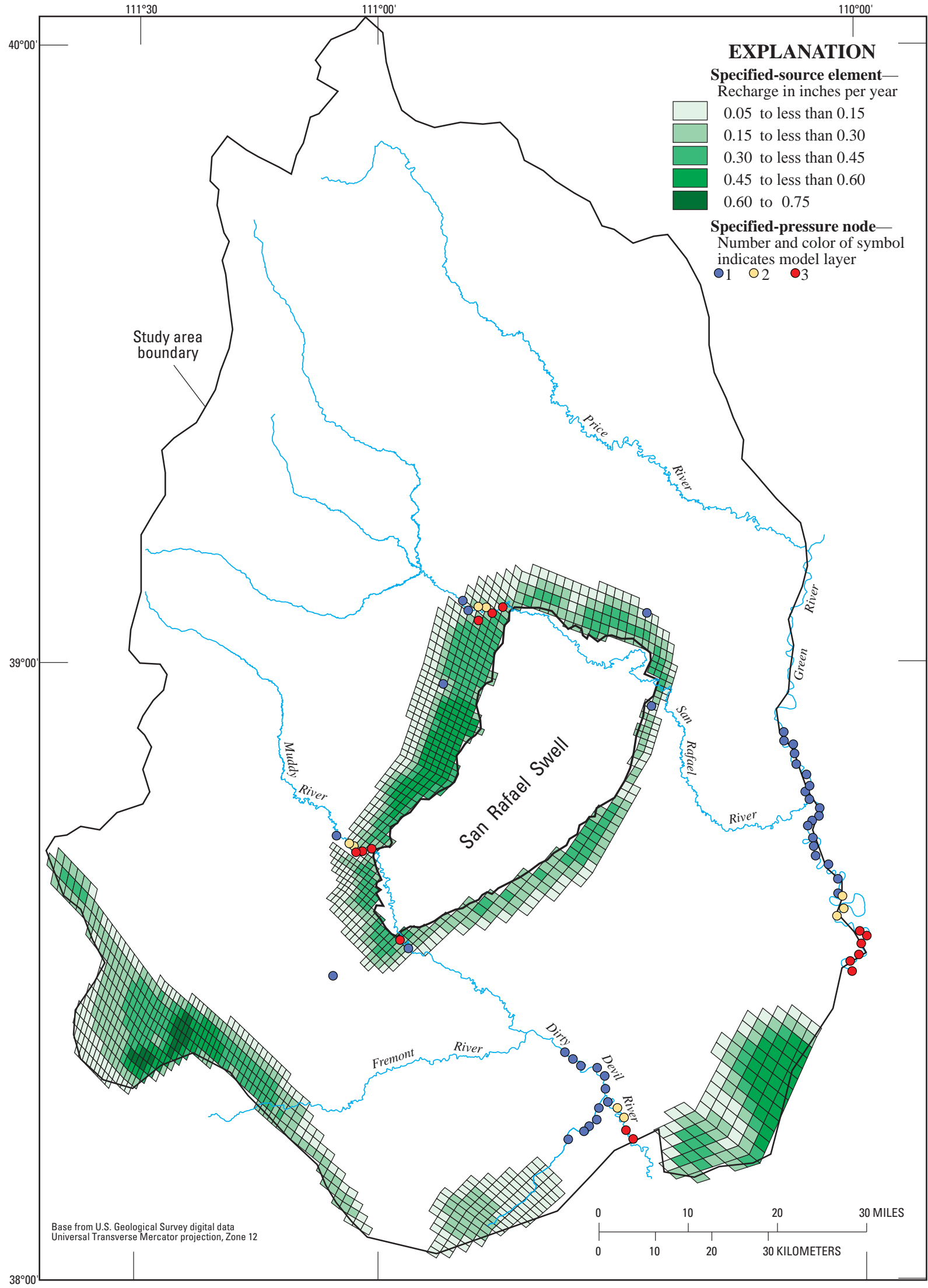

Figure 11. Elements where sources of fluid and solute are specified to simulate recharge, and nodes where water pressures are specified to simulate discharge at rivers and springs in the Glen Canyon aquifer study area, Utah. 
values. Scaling was done to simulate the presence of more fine-grained deposits within the Kayenta Formation and Wingate Sandstone. Model layers were specified as horizontally isotropic and vertically anisotropic. Vertical permeability was assigned as 0.1 of the horizontal value.

Initial porosity values and distribution were made on the basis of estimates of porosity for the Glen Canyon aquifer. Initial porosity for model layer 1 was assigned as shown in figure 7a. Layer 2 porosity was assigned a value 0.05 higher than layer 1; layer 3 was assigned a value 0.02 higher than layer 1 . As with permeability, the vertical adjustment of porosity was done to simulate more fine-grained deposits within the Kayenta Formation (layer 2) and Wingate Sandstone (layer 3).

A solid-matrix compressibility value of $1 \times 10^{-10} \mathrm{~ms}^{2} / \mathrm{kg}$ was assigned to all model layers. This value approximates a generalized compressibility for sound rock (Freeze and Cherry, 1979, table 2.5). There are no available data to define dispersivity of the Glen Canyon aquifer. Therefore, values of $50 \mathrm{~m}$ and $5 \mathrm{~m}$ were estimated for longitudinal and transverse directions, respectively, and assigned to all model layers. Values were based on the scale of transport (Gelhar and others, 1992).

\section{Fluid Properties}

Fluid properties needed for variable-density solute transport simulation include the compressibility of water, coefficient of fluid density change as a function of concentration, dissolved-solids concentration of water in the aquifer and the injected water, fluid density of water, and fluid viscosity. The compressibility of water was assigned a general value of $4.4 \times 10^{-10} \mathrm{~ms}^{2} / \mathrm{kg}$ (Voss and Provost, 2002, p. 18). The coefficient of fluid-density change with concentration was set at $700 \mathrm{~kg} / \mathrm{m}^{3}$. The values assigned for fluid density and viscosity are the same as used in the conversion from hydraulic conductivity to permeability.

A map depicting the distribution of the dissolved-solids concentration for the top of the Glen Canyon aquifer was constructed from fluid analyses provided by injection-well operators and from Freethey and others (1988) (fig. 9a). A generalized version of the distribution (fig. 9b) was used to assign an initial concentration to each node representing the Navajo Sandstone. Where specified-source elements exist (fig. 11), the solute concentration of the source fluid was assigned a value on the basis of the dissolved-solids distribution. Because adequate data were not available to describe water quality in each layer, individual model layer values were assigned using a multiplier. The multipliers were derived from multiple-depth sample analyses for wells in the coal-bed methane production areas. On average, the concentrations for water in the Kayenta Formation and the Wingate Sandstone were 1.2 and 1.7 times higher than the dissolved-solids concentration in the Navajo Sandstone. Thus, the multipliers 1.0, 1.2, and 1.7 were used to assign dissolvedsolids concentrations to each node in layers 1,2, and 3 of the model. Density of the fluids and the resulting gravity component of movement is derived from the dissolved-solids concentrations in each layer.
The dissolved-solids concentration of the injected water was determined from laboratory analyses conducted by the well operators and provided to the Utah Division of Oil, Gas, and Mining for each year of injection. Because this information was not available for 2004, values for 2003 were also used for 2004.

\section{Reference Model}

Aquifer and fluid properties are estimated for large portions of the Glen Canyon aquifer; however, property values based on in situ and laboratory measurements and analyses are limited. Given these data constraints, development of a fully calibrated simulation of the flow and solute system was not feasible. Instead, an uncalibrated reference model was constructed that is a plausible representation of the conceptual flow and solutetransport processes presented in this report. The simulation was considered plausible if 1) discharge was simulated at all specified-pressure nodes representing ground-water discharge to the Muddy, Dirty Devil, San Rafael, and Green Rivers, 2) residuals between fresh-water equivalent water levels derived from simulated pressures and concentrations and measured water levels at the 12 observation points were unbiased (fig. 12), and 3) simulated ground-water flow directions were comparable to the conceptualized directions of flow. The reference model was developed using steady-state flow conditions and a 1-day transient transport time period. Transport was not run to steady state because brine water sources are not represented in the model; only solute sources from recharge are included (figs. 8 and 11). The 1-day transient period integrates the density variability created by the general distribution of dissolved-solids concentrations (fig. 9b) into the reference model. This approach makes the reference model results comparable to model simulations that incorporate injection of coal-bed methane production water.

In order to meet the three "plausibility" criteria, the simulated permeability was reduced to about 75 percent of initial values determined from hydraulic-conductivity estimates (fig. 13). The criteria also could be met by maintaining initial estimates of permeability and increasing recharge by 25 to 30 percent from initial estimates of 15,000 acre-ft/yr (table 1). Permeability routinely varies by several orders of magnitude within heterogeneous aquifer systems and is poorly quantified in the study area. Applying that perspective, simulated permeabilities were reduced and recharge was not changed from the initial estimate.

The final porosity distribution for model layer 1 (Navajo Sandstone) is shown in figure 14. Final porosity values for layers 2 and 3 are scaled from layer 1 as discussed in the "Aquifer Properties" section. The simulated distribution of water levels for model layer 1 (Navajo Sandstone) resulted in ground-water flow directions (fig. 15) that are similar to those conceptualized. Both the area of active ground-water movement and the area of little or negligible ground-water movement, shown in figure 8 , are simulated. Figure 15 also 


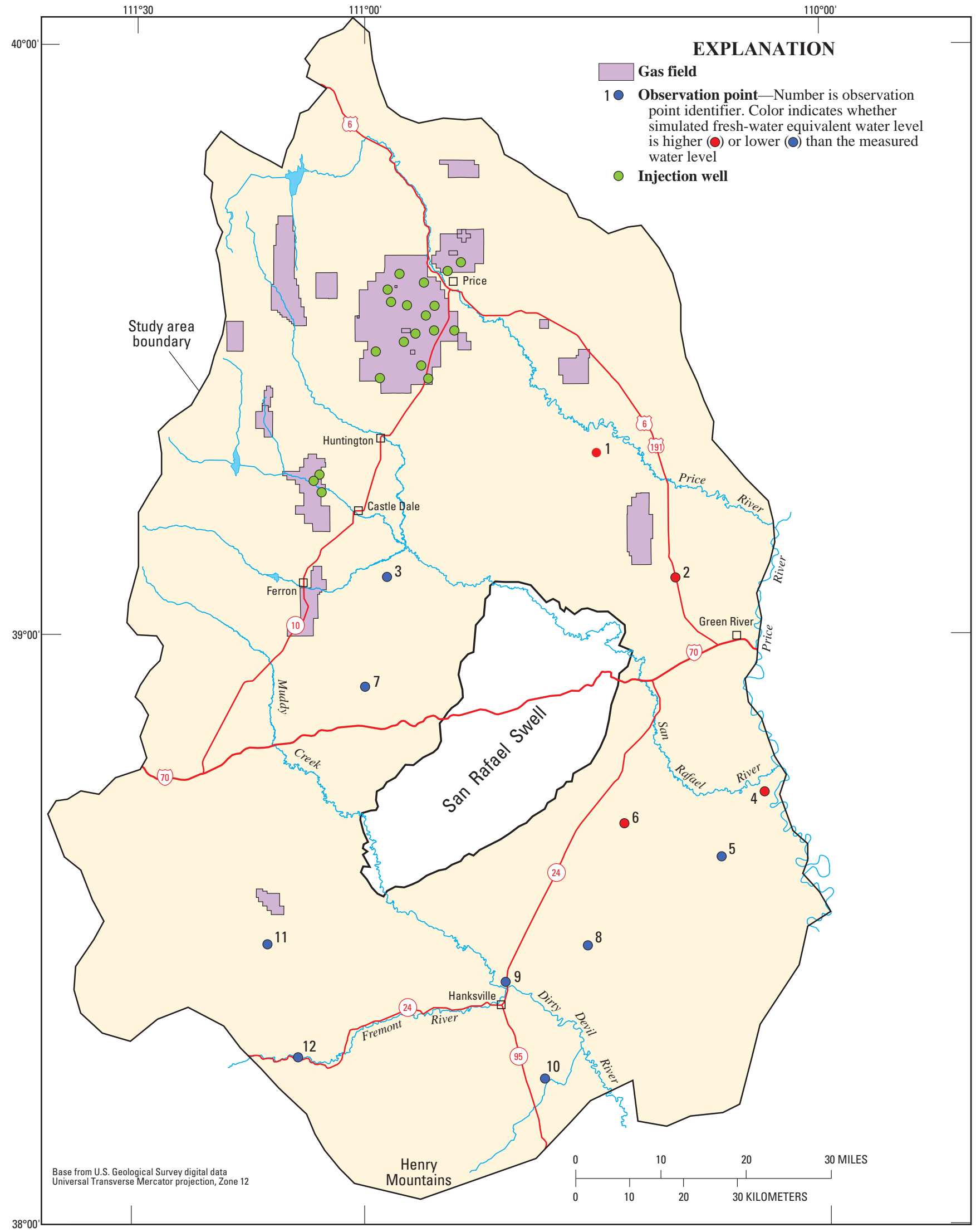

Figure 12. Observation points used to adjust permeability and to estimate projected changes in fresh-water equivalent water levels and dissolved-solids concentrations in the model of the Glen Canyon aquifer study area, Utah. 


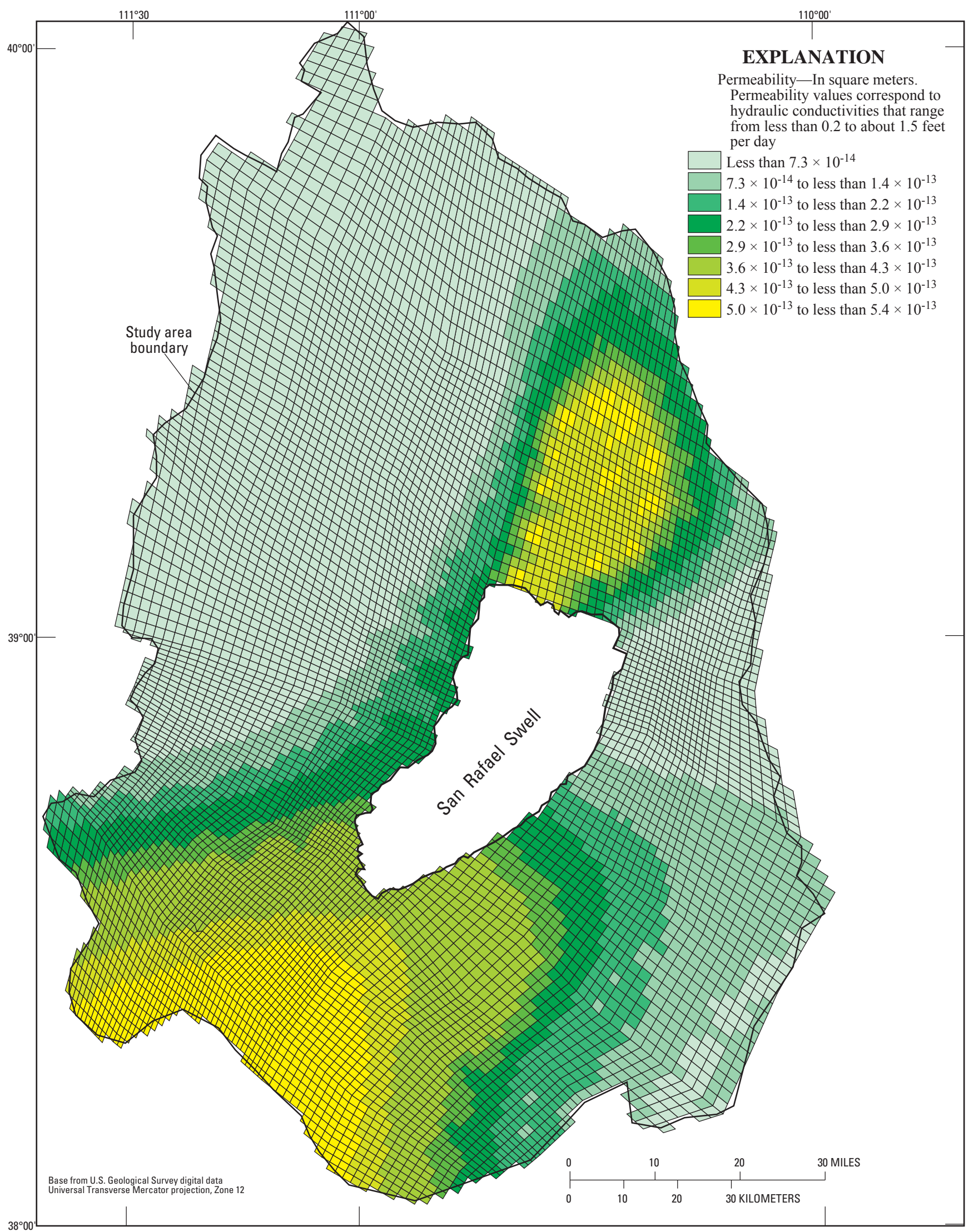

Figure 13. The final distribution of horizontal permeability values for the Navajo Sandstone (model layer 1) as simulated in the reference model of the Glen Canyon aquifer study area, Utah. 


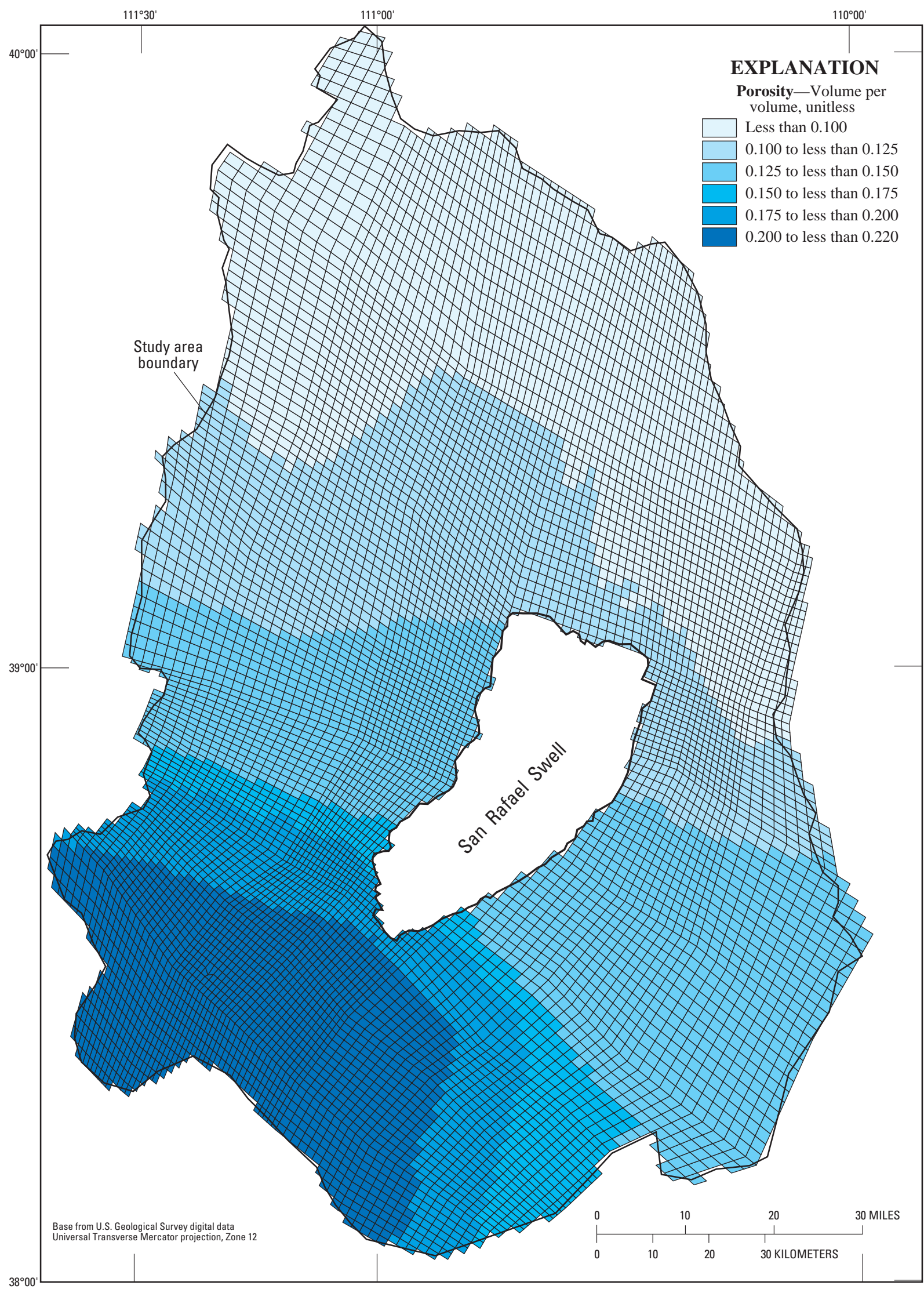

Figure 14. Final distribution of porosity values for the Navajo Sandstone (model layer 1) as simulated in the reference model of the Glen Canyon aquifer study area, Utah. 


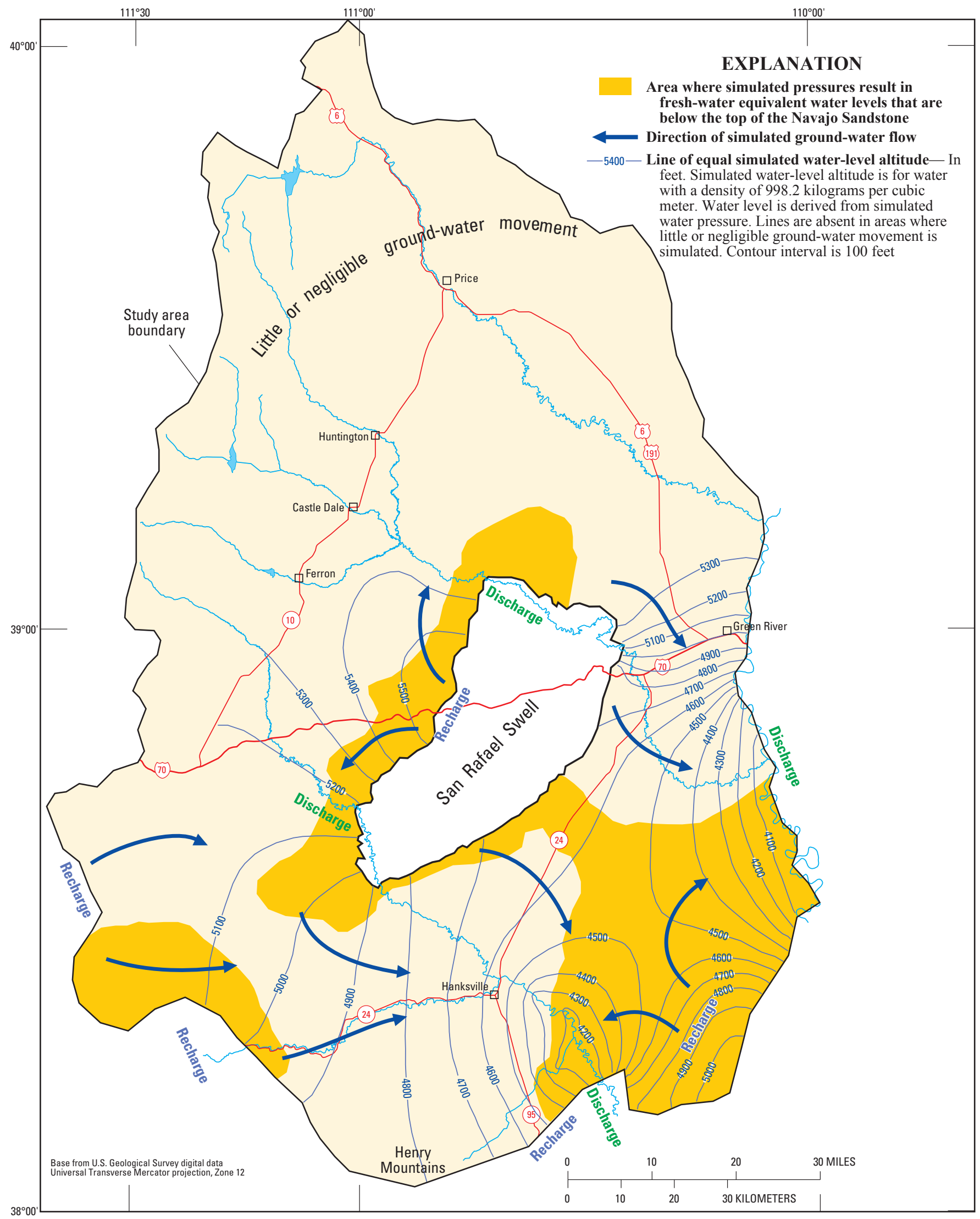

Figure 15. Direction of ground-water flow in the Navajo Sandstone (model layer 1 ) and areas where fresh-water equivalent water levels are below the top of the Navajo Sandstone as simulated in the reference model of the Glen Canyon aquifer study area, Utah. 
shows areas where simulated pressures result in fresh-water equivalent water levels that are below the top of the Navajo Sandstone. The model as constructed considers only fully saturated conditions (see the "Numerical Simulation" section of this report). As a result, simulated pressure gradients, fluid volumes into and out of aquifer storage, and fluid velocities for these nodes are less than would be calculated if unsaturated conditions were considered. The locations shown on fig. 15 generally correspond to higher topographical areas of the Glen Canyon aquifer study area, where water-table conditions likely exist.

The amounts of ground-water flow simulated in the reference model are similar to conceptualized amounts (table 3). Simulated transport of dissolved solids to specified-pressure boundaries (rivers and springs) is about 16,000 tons/yr. This exceeds the simulated solute input from specified-source elements by about 20 percent. The solute solution is not in steady state and the amount of simulated transport to specifiedpressure boundaries is a function of the initial concentration assigned to model nodes near those boundaries (fig. 9b and the "Fluid Properties" section of this report). Available data are insufficient to estimate a conceptual solute budget; it is not known how the simulated amount and imbalance compare to actual conditions. In spite of the solute imbalance, modeling is considered adequate to evaluate differences between pre- and post-injection conditions.

\section{Injection Model}

Stresses imposed on the system by injection of coal-bed methane production water were simulated to evaluate potential transient regional-scale effects of the injection. The injection model simulates variable-density transient ground-water flow and solute transport (Voss and Provost, 2002, p. 204). Initial pressures for the injection model are the steady-state output pressures simulated by the reference model (see fig. 15 for resulting flow directions). Initial concentrations are the same as those used for the reference model and are shown on figure $9 \mathrm{~b}$.

Injection was simulated for 16 years from July 1994 through June 2010 using six consecutive stress periods (table 4). Stress periods 1 through 4 simulate measured injection rates and concentrations. Stress periods 5 and 6 simulate projected injection rates and concentrations. Stress period 7 simulates a 20 -year recovery period with no injection. Results of injection are compared to a transient version of the reference model that simulates 36 years with no injection. In this way, changes in concentration due to injection are measured relative to changes that are independent of injection, and the effects due to the initial concentration distribution are removed.

The impact of coal-bed production water is measured in terms of pressure, and concentration changes at the end of stress period 7 (table 3). Pressure increase is expressed in terms of fresh-water equivalent water levels. Figure 16a shows the area (approximately $900 \mathrm{mi}^{2}$ ) where simulated water-level increases are greater than $50 \mathrm{ft}$; the maximum increase in this area is $150 \mathrm{ft}$. Figure $16 \mathrm{~b}$ shows the area (approximately 400 $\mathrm{mi}^{2}$ ) where dissolved-solids concentration increased by more than $100 \mathrm{mg} / \mathrm{L}$; the maximum increase is $740 \mathrm{mg} / \mathrm{L}$. These areas represent conditions after a 20 -year recovery period with no injection. Equivalent water levels at the end of injection (stress period 6) are on the order of 500 to $600 \mathrm{ft}$ at the specific nodes where injection wells are simulated. Maximum concentration increase at the end of injection (stress period 6) was $610 \mathrm{mg} / \mathrm{L}$. In most cases, the injection fluid has a lower dissolved-solids concentration than the ground water it is being injected into. This results in lower simulated concentrations (on the order of several thousand $\mathrm{mg} / \mathrm{L}$ ) at selected injection nodes. In general however, intensifying pressure causes concentration in the Navajo Sandstone in the vicinity of injection to increase.

Farther away, the effects of pressurized injection are reduced. Aquifer storage tends to attenuate and delay the effects, and the injected water is accrued as increased storage. West and north of the San Rafael Swell, the maximum rise in water levels is less than $15 \mathrm{ft}$ (figs. 12 and 17a, observation points 1, 2, 3, and 7). To the southeast of the Swell (fig. 17a, observation points $5,6,8,9)$, pressures and water-level change is negative (that is, they decrease slightly). Simulated concentration change at all observation points is less than $2 \mathrm{mg} / \mathrm{L}$ at the end of stress period 7. There is essentially no increase in the simulated amounts of flow and solute load to the specifiedpressure nodes representing the Muddy, Dirty Devil, San Rafael, and Green Rivers due to injection (fig. 17b). Both change and amount shown on figure 17 are calculated as the difference between the 36-year simulations without and with injection, as discussed previously.

Other than areas near injection, changes in pressure, flow, and concentration over the 36-year period are less than the resolution accuracy of the numerical simulation. Although injected mass will eventually be removed from the Glen Canyon aquifer, cursory evaluations indicate that this process will take thousands of years. Because the sources of brine are unknown, it is not possible to separate between natural and injection effects on solute loading to the rivers over those longer time scales. The simulation shows that at a time scale of tens of years, modeled injection rates and amounts do not significantly increase hydrologic interaction between areas of active and little or negligible flow and solute load to the rivers.

\section{Injection Model Uncertainty}

The intended use of the injection model is to assess regional-scale effects of pressurized injection. One of those effects is the potential increase of solute inflow to the Muddy, Dirty Devil, San Rafael, and Green Rivers due to injection. To that end, the injection model uncertainty is measured in terms of simulated inflow of solute to the rivers. Model parameters that represent porosity, longitudinal dispersivity, and vertical permeability were varied and change in simulated outflow of solute mass to the rivers for the last time step of the injection model (2030) are shown on figure 18. 
Table 3. Simulated ground-water and solute budgets for the reference model, the 36 -year reference model, the injection model at the end of stress period 7, and the conceptual ground-water budget for the Glen Canyon aquifer study area, Utah.

[-, no data; NC, not conceptualized]

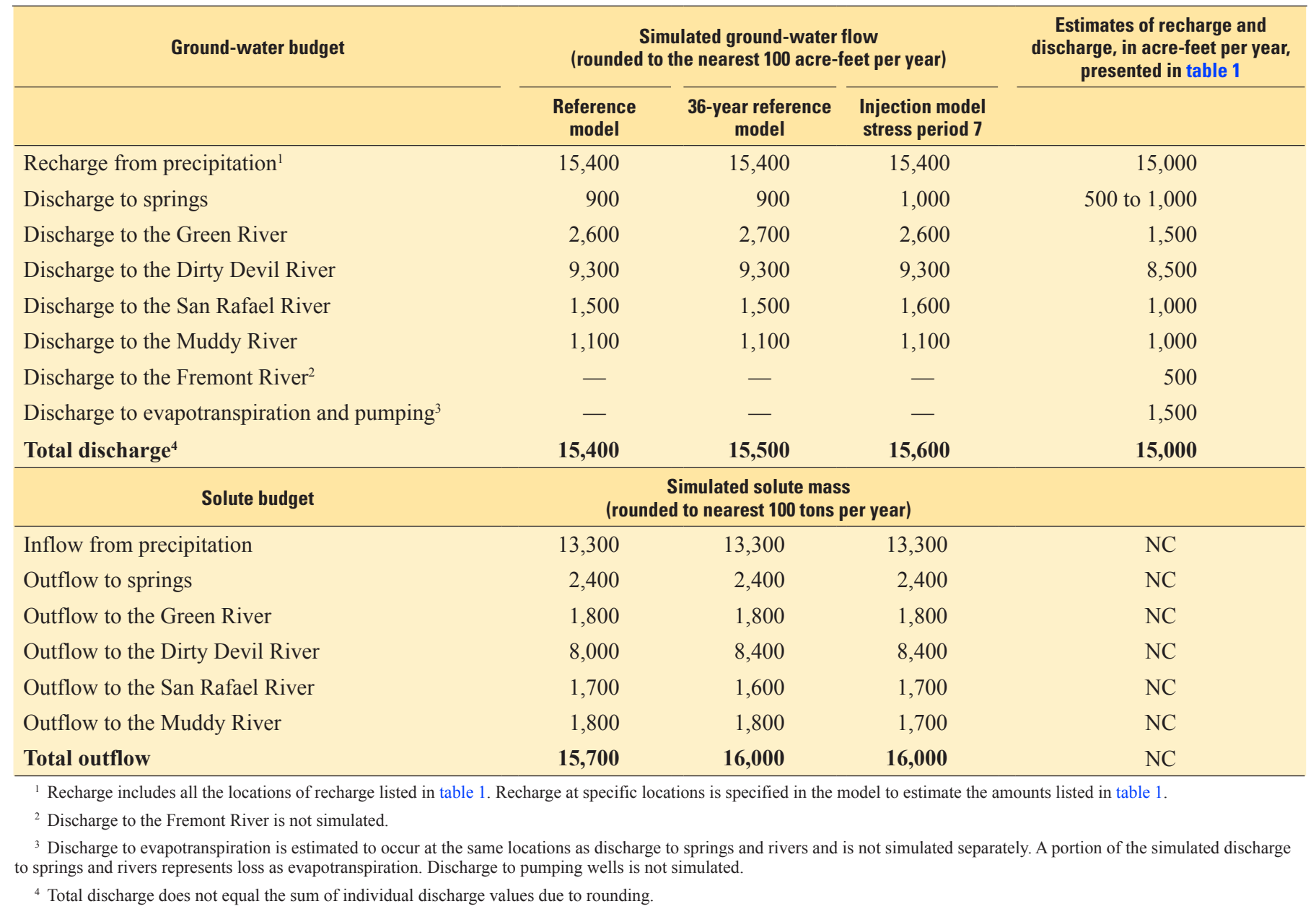

Table 4. Stress periods and amounts of injected coal-bed methane production water that is simulated in the injection model of the Glen Canyon aquifer study area, Utah.

\begin{tabular}{|c|c|c|c|}
\hline $\begin{array}{c}\text { Stress } \\
\text { period }\end{array}$ & $\begin{array}{c}\text { Simulation } \\
\text { period }\end{array}$ & $\begin{array}{c}\text { Rate of fluid } \\
\text { injection } \\
\text { (acre-feet per } \\
\text { year) }\end{array}$ & $\begin{array}{c}\text { Average } \\
\text { concentration of } \\
\text { solute injected } \\
\text { (milligrams per } \\
\text { liter) }\end{array}$ \\
\hline 1 & $1994-1996$ & 241 & 8,479 \\
\hline 2 & $1996-2000$ & 2,277 & 10,157 \\
\hline 3 & $2000-2002$ & 4,178 & 13,170 \\
\hline 4 & $2002-2004$ & 3,321 & 16,793 \\
\hline 5 & $2004-2007$ & 2,014 & 16,502 \\
\hline 6 & $2007-2010$ & 461 & 16,539 \\
\hline 7 & $2010-2030$ & 0 & 0 \\
\hline
\end{tabular}

Porosity was decreased to simulate faster transport velocities throughout the aquifer. Longitudinal dispersion was increased to simulate faster velocities for the leading edge of any solute mass mobilized due to injection. Vertical permeability was increased to allow a better hydrologic connection between active and negligible flow areas of the aquifer. In all cases, parameter variations resulted in a plausible representation of flow and transport processes (see section titled "Reference Model") and had minimal effect on simulated discharge and solute load to the rivers (fig. 18). 


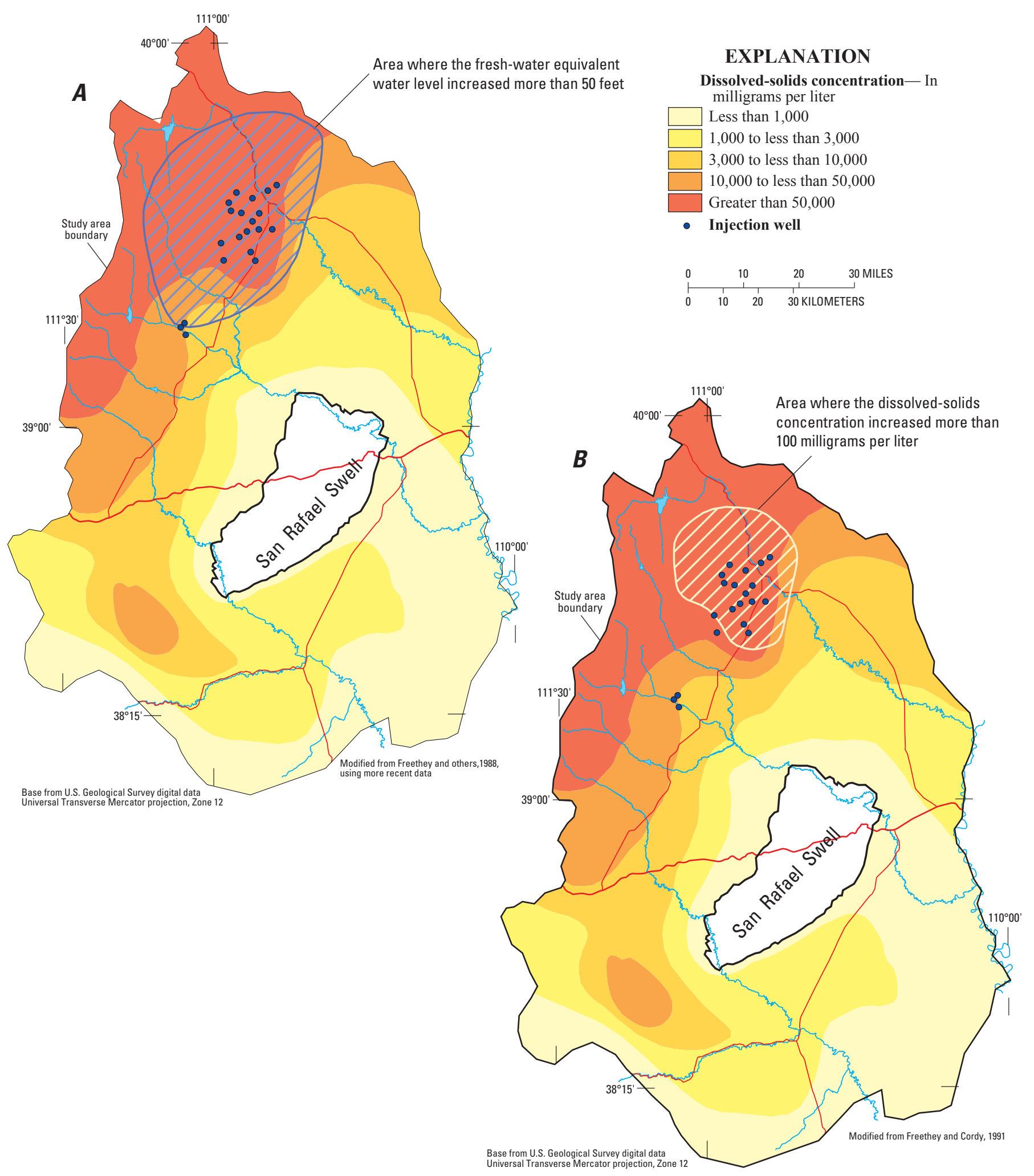

Figure 16. Areas where $A$, fresh-water equivalent water levels changed by more than 50 feet and $B$, dissolved-solids concentrations changed by more than 100 milligrams per liter, overlain on the dissolved-solids concentration distribution simulated for the Navajo Sandstone (model Layer 1 ) at the end of stress period 7 in the injection model of the Glen Canyon aquifer study area, Utah. 

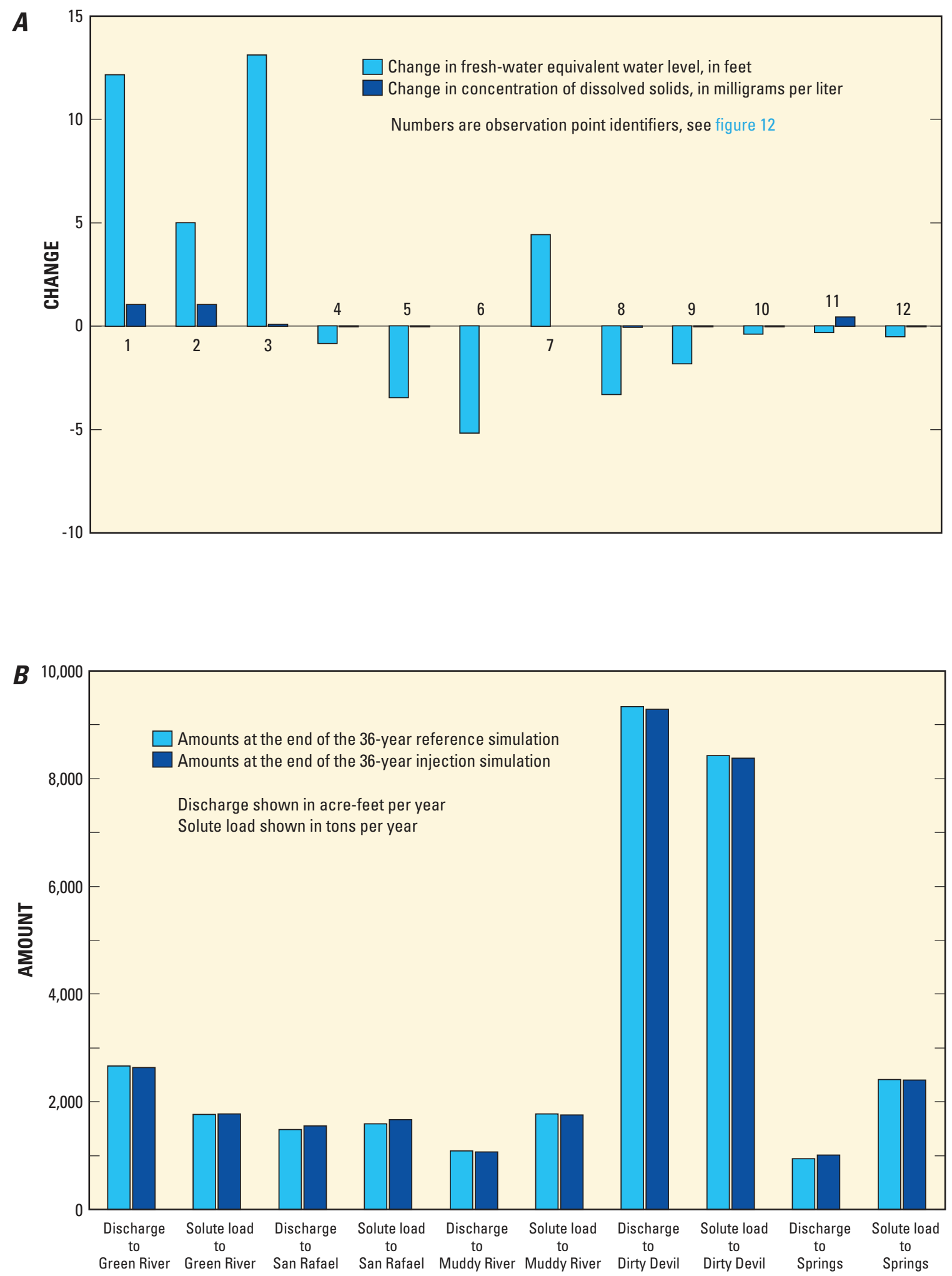

Figure 17. A, changes in fresh-water equivalent water levels and concentrations of dissolved solids, and $B$, amounts of discharge and solute load to rivers, simulated for the Glen Canyon aquifer study area, Utah. 


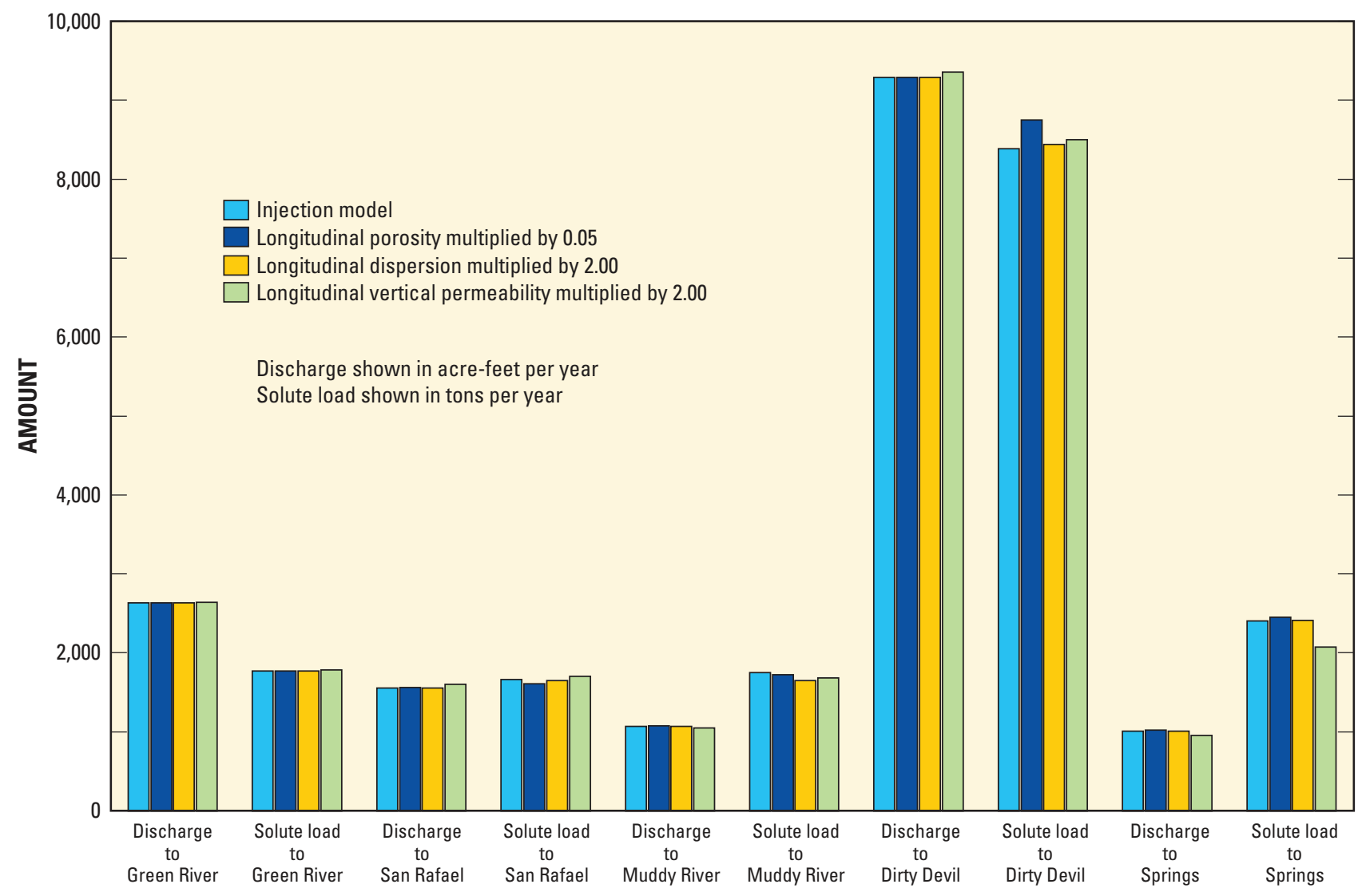

Figure 18. Amounts of discharge and solute load to rivers simulated at the end of stress period 7 in the injection model of the Glen Canyon aquifer study area, Utah.

\section{Model Limitations}

Simulations developed for this study are generalized and not useful for site-specific comparisons of discharge or water levels. The scale of the reference model and the lack of field measurements for comparison preclude detailed analyses. Model uncertainty of simulated ground-water storage (represented in terms of solid-matrix and water compressibility) was not tested. Storage tends to attenuate and delay the effects of pressurized injection. If simulated storage was decreased, simulated water levels and resulting discharge of water and solutes to rivers may increase. Data from exploration drilling indicate that pockets of gas may exist in the areas of pressurized injection. These gas pockets are compressible and could provide volume to store water and solutes. If these conditions exist, aquifer storage would be greater than simulated, thereby mitigating the effects of pressurized injection.

The model and simulations were designed as tools to explore general relations between recharge and discharge volumes and general changes in dissolved-solids concentration between areas of fluid inflow and outflow as the system is placed under the stress of injection. The reference model is generalized and is not fully calibrated.

\section{Summary}

The extraction of methane from coal beds in the Ferron coal trend in central Utah started in the mid-1980s. Beginning in 1994, production water from the extraction process was pressure injected into the Glen Canyon aquifer. The lateral extent of the aquifer that could be affected by injection is about 7,600 square miles. To address these regional-scale effects, the U.S. Geological Survey in cooperation with the Utah Department of Natural Resources, Division of Oil, Gas, and Mining, developed a conceptual model of groundwater movement and transport of dissolved solids in the Glen Canyon aquifer. A numerical model that incorporates aquifer concepts was then constructed and used to simulate injection. The intended use of the numerical simulation is as a scoping tool to assess regional-scale effects of pressurized injection of coal-bed methane production water over a decadal time frame.

The Glen Canyon aquifer within the study area is conceptualized in two parts - an active area of ground-water flow and solute transport that exists between recharge areas in the San Rafael Swell and Desert, Waterpocket Fold, and Henry Mountains, and discharge locations along the Muddy, Dirty Devil, San Rafael, and Green Rivers. An area of little or negligible ground-water flow exists north of Price, Utah, and 
beneath the Wasatch Plateau. Pressurized injection of coal-bed methane production water occurs in this area where dissolvedsolids concentrations can be more than 100,000 milligrams per liter. Injection has the potential to increase hydrologic interaction with the active flow area, where dissolved-solids concentrations are generally less than 3,000 milligrams per liter.

In 1994 coal-bed methane producers began pressurized injection of production water from relatively shallow coal-bed methane gas production wells into the deeper Glen Canyon aquifer. This initiated a net addition of flow and mass of solutes into the aquifer. The total amount of water injected from 1994 through 2004 was about 25,000 acre-feet. A three-dimensional finite-element model was used to simulate ground-water flow and transport and the possible effects of this injection. Data constraints precluded the development of a fully calibrated simulation. Instead, an uncalibrated reference model was constructed that is a plausible representation of the conceptual flow and solute-transport processes prior to pressurized injection. Simulated flow directions and dissolvedsolids concentrations are similar to those conceptualized.

Simulated water levels and dissolved-solids concentrations in the injection areas increased by 50 feet and 100 milligrams per liter or more, respectively. These increases are accrued into aquifer storage and do not extend to the rivers during the 36-year simulation period. The amount of change in simulated discharge and solute load to the rivers is less than the resolution accuracy of the numerical simulation and is interpreted as no significant change over the simulated time period. Analysis of injection model uncertainty indicates that simulating faster velocities and better hydrologic connections between active and little or negligible flow areas of the aquifer has minimal effect on simulated solute inflow to rivers.

\section{References Cited}

Cordy, G.E., Seiler, R.L., and Stolp, B.J., 1993, Hydrology of the L.C. Holding coal-lease tract and adjacent areas, southwestern Utah, and potential effects of coal mining: U.S. Geological Survey Water-Resources Investigations Report 91-4111, 84 p. Available at http://pubs.er.usgs.gov/ publication/wri914111.

Freethey, G.W., Kimball, B.A., Wilberg, D.E., and Hood, J.W., 1988, General hydrogeology of the aquifers of Mesozoic age, Upper Colorado River Basin — excluding the San Juan Basin - Colorado, Utah, Wyoming, and Arizona: U.S. Geological Survey Hydrologic Investigations Atlas 698, 2 sheets.

Freethey, G.W., and Cordy, G.E., 1991, Geohydrology of Mesozoic rocks in the Upper Colorado River Basin in Arizona, Colorado, New Mexico, Utah, and Wyoming, excluding the San Juan Basin: U.S. Geological Survey Professional Paper 1411-C, 118 p. Available at http://pubs. er.usgs.gov/publication/pp1411C.
Freeze, R.A., and Cherry, J.A., 1979, Groundwater: Englewood Cliffs, New Jersey, Prentice-Hall, 604 p.

Gelhar, L.W., Welty, C., and Rehfeldt, K.R., 1992, A critical review of data on field-scale dispersion in aquifers: Water Resource Research, v. 28, no. 7, p. 1955-1974.

Hood, J.W., and Danielson, T.W., 1981, Bedrock aquifers in the lower Dirty Devil River basin area, Utah, with special emphasis on the Navajo Sandstone: State of Utah Department of Natural Resources Technical Publication No. $68,143 \mathrm{p}$.

Hood, J.W., and Patterson, D.J., 1984, Bedrock aquifers in the northern San Rafael Swell area, Utah, with special emphasis on the Navajo Sandstone: State of Utah Department of Natural Resources Technical Publication No. 78, 128 p.

Nuccio, V., 1997, Coalbed methane-An untrapped energy resource and an environmental concern: U.S. Geological Survey Fact Sheet FS-019-97. Available at http://energy. usgs.gov/factsheets/Coalbed/coalmeth.html.

Voss, C.I., and Provost, A.M., 2002, SUTRA-A model for saturated-unsaturated, variable density ground-water flow with solute and energy transport: U.S. Geological Survey Water-Resources Investigations Report 02-4231, $250 \mathrm{p}$. Available at http://pubs.er.usgs.gov/publication/ wri024231.

Weigel, J.F., 1987, Selected hydrologic and physical properties of Mesozoic formations in the Upper Colorado River Basin in Arizona, Colorado, Utah, and Wyoming - excluding the San Juan Basin: U.S. Geological Survey Water-Resources Investigations Report 86-4170, 68 p. Available at http:// pubs.er.usgs.gov/publication/wri864170.

Weiss, Emanuel, 1987, Ground-water flow in the Navajo Sandstone in parts of Emery, Grand, Carbon, Wayne, Garfield, and Kane Counties, southeast Utah: U.S. Geological Survey Water-Resources Investigations Report 86-4012, 41 p. Available at http://pubs.er.usgs.gov/publication /wri864012.

Winston, R.B., and Voss, C.I., 2004, SutraGUI-A graphical user interface for SUTRA, a model for ground-water flow with solute and energy transport: U.S. Geological Survey Open-File Report 03-285, 114 p. Available at http://pubs. er.usgs.gov/publication/ofr03285. 



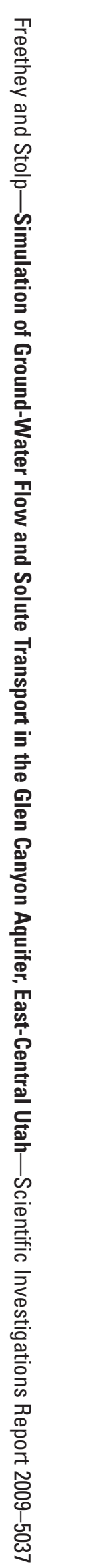

